\title{
Changes in quality characteristics of salted Kimchi cabbage and kimchi paste during storage
}

\author{
Hye-Yeon Song, Seon-Hwa Cheon, SeungRan Yoo, Young Bae Chung, Hye-Young Seo* \\ World Institute of Kimchi, Gwangju 61755, Korea
}

\section{절임배추 및 김치 양념의 저장기간 중 품질 특성 변화}

\author{
송혜연·천선화·유승란·정영배·서혜영* \\ 세계김치연구소
}

\begin{abstract}
This study was conducted to determine the potential use for salted Kimchi cabbage and kimchi paste by analyzing the quality characteristic of kimchi prepared with stored them. Salted Kimchi cabbages were packed with the $2 \%$ brine and kimchi paste were stored at $4^{\circ} \mathrm{C}$ for 8 weeks, respectively. Kimchi prepared at 0 day and kimchi prepared with stored salted Kimchi cabbage and kimchi paste every week were stored at $4^{\circ} \mathrm{C}$ for 8 weeks. The salinity and titratable acidity of salted Kimchi cabbage packed with the brine was lower than control. The results of salinity, pH and moisture contents of kimchi paste did not show any significant differences during storage, however, the titratable acidity was increased. In sensory evaluation, salted Kimchi cabbage packed with the brine showed higher score in overall preference than control. Kimchi paste showed 4.9 6.1 score in overall preference during storage. The titratable acidity of kimchi prepared with stored salted Kimchi cabbage and kimchi paste was lower than control. But, the results of sensory evaluation did not show significant difference among treatments. The study suggested that the use of $2 \%$ brine is an effective way for extending shelf-life of salted Kimchi cabbage and Kimchi prepared with stored salted Kimchi cabbage and kimchi paste every week is effective to delay the fermentation but no difference in sensory evaluation.
\end{abstract}

Key words : kimchi, salted Kimchi cabbage, kimchi paste, brine, quality characteristics

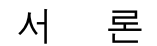

김치는 배추, 무, 오이 등과 같은 채소를 절인 후 고춧가 루, 마늘, 생강, 젓갈류 등 다양한 양념을 첨가하여 발효시킨 한국의 전통발효식품이며(1), 절임채소의 종류에 따라서 김치의 종류도 다양하며 그 중 배추김치가 가장 일반적이 다. 최근에는 김치뿐만 아니라 김치 제조용 절임배추를 포 장하여 판매하고 있으며, 김치 제조 시 가장 많은 시간이 소요되는 절임배추 제조시간을 단축할 수 있어 김치를 보다

*Corresponding author. E-mail : hyseo@wikim.re.kr Phone : 82-62-610-1731, Fax : 82-62-610-1850

Received 29 April 2016; Revised 17 June 2016; Accepted 11 August 2016.

Copyright (c) The Korean Society of Food Preservation. All rights reserved.
편리하게 제조할 수 있게 되었다(2). 또한 맞벌이 부부 및 소득 증가 등 사회변화에 따른 식생활 변화로 절임배추를 이용하는 소비자의 비율이 김장철뿐만 아니라 연중 점차 증가하고 있는 추세이며, 절임배추와 완성된 양념을 구매 하여 간편하게 제조한 뒤 김치를 섭취하는 소비자들이 증가 하고 있다 $(3,4)$.

배추를 소금에 절이는 과정은 김치를 제조하는 시작단계 로 배추의 선별, 이절, 절임, 세척, 탈수 등 복잡한 과정을 통해 절임배추가 제조된다. 이렇게 제조된 절임배추는 절 임과정에 의해 젖산균 등 미생물의 생육이 용이해지는 상태 로 저장기간이 일반적으로 1 주 이내로 비교적 짧기 때문에 포장방법(5-7), 세척방법(8), 저장방법(9) 등 다양한 측면에 서 절임배추의 저장기간 연장에 관한 연구가 진행되었다. 그러나 대부분의 연구는 절임배추를 저온 $\left(0^{\circ} \mathrm{C}\right)$ 에서 저장하 면서 저장기간에 따른 $\mathrm{pH}$, 산도, 미생물 수 변화 등을 분석 
하였으며, 장기 저장 후 실제로 소비자가 가식할 수 있는지 에 대한 관능검사 결과는 부족한 상황이다. 최근에는 김치 원료의 수급안정화를 위한 목적으로 생배추를 빙결점 $\left(0^{\circ} \mathrm{C}\right)$ 을 이용하여 절임하면서 장기간(60일 이상) 저장할 수 있는 절임기술이 개발되었으며, 김치 제조 결과 일반김치와 비 교하여 제조 초기에는 약간의 차이가 있으나 7-10일 저온 숙성한 경우 품질이 양호하다고 보고한 바 있다(10). 그러나 이는 유통제품이 아닌 김치제조 현장에서 활용할 수 있는 기술로 소비자를 대상으로 한 절임배추 저장 중 품질 특성 및 김치제조 특성에 대한 연구가 더 필요하다.

김치 양념은 지역, 종류, 계절 등에 따라 다양하지만 주로 고춧가루, 마늘, 생강, 젓갈 등을 첨가하여 제조된다. 이렇 게 첨가된 재료들은 살균작용을 나타내어 김치가 지나치게 과숙되는 것을 방지하고 가식기간을 늘려주며, 젓갈은 김 치의 감칠맛을 내는데 도움을 준다(11-13). 김치 양념에 관 한 연구는 부재료가 배추김치 숙성에 미치는 영향(14-16), starter 및 멸치액젓 첨가가 김치 양념 및 겉절이 김치의 품질에 미치는 영향(17) 등이 진행되었다. 대부분의 연구가 김치 양념 단독으로 저장하여 품질을 평가한 것이 아니라 완성된 김치 형태를 대상으로 품질 특성 연구가 이루어져 있어 절임배추와 구성되어 동일 저장기간 경과 후에 김치로 제조하여 섭취하였을 때에 대한 품질평가는 지속적으로 필요하다.

따라서, 본 연구에서는 최근 소비가 늘어나고 있는 절임 배추 및 김치 양념으로 구성된 세트상품에 대한 기본적인 품질 특성 정보를 제공하고자 각각의 저장 중 품질 특성을 분석하였다. 또한 분리 저장된 절임배추와 김치 양념을 혼 합하여 김치로 제조한 후 처음부터 김치 형태로 제조하여 저장한 김치와 품질 특성을 비교하여 분리하여 저장한 경우 발효 지연 효과가 있는지 가능성을 검토하여 소비자가 직접 제조하는(DIY, do it yourself) 김치세트 제품 개발을 위한 기초자료로 활용하고자 하였다.

\section{재료 및 방법}

\section{실험재료}

본 실험에 사용된 배추는 광주광역시 농수산물 시장에서 구입한 전라남도 순창에서 수확한 대통 품종을 사용하였 다. 염수 제조 시 사용한 정제염은 전라남도 신안군에서 생산한 한주소금을 구매하여 사용하였다. 또한 양념 제조 시 사용한 고춧가루, 무, 마늘, 생강, 파, 멸치액젓, 찹쌀풀 등은 농수산물 시장에서 구입하여 사용하였다.

\section{절임배추 제조}

배추를 당일 구매하여 다듬어 이절한 후, 이절된 배추를 정제염을 사용하여 만든 $10 \%$ 염수에 16 시간 절인 후 3 회
세척하여, 염도 $1.7 \%$ 의 절임배추를 제조하였다. 제조된 절 임배추는 $2 \%$ 염수에 침지하지 않고 포장하거나 절임배추 의 중량 대비 0.5 배 및 1.0 배의 $2 \%$ 염수에 침지하여 포장하 였으며 포장지는 $\mathrm{PE}$ 를 사용하였다. 포장된 절임배추는 $4^{\circ} \mathrm{C}$ 에 저장하면서 1 주 간격으로 이화학적, 미생물학적 및 관능 적 품질 특성을 분석하였다.

\section{김치 양념 제조}

김치 양념은 Table 1 과 같은 배합비율로 제조하여 $\mathrm{PE}$ $\mathrm{bag}$ 에 포장하였다. 포장된 김치 양념은 $4^{\circ} \mathrm{C}$ 에서 8 주간 저장 하면서 1 주 간격으로 이화학적, 미생물학적 및 관능적 품질 특성을 분석하였다.

Table 1. Percentage composition of ingredient for kimchi paste

\begin{tabular}{cc}
\hline Ingredients & Percentage composition (\%) \\
\hline Red pepper & 15 \\
Radish & 15 \\
Galic & 12.5 \\
Ginger & 4 \\
Green onion & 12.5 \\
Anchovy sauce & 15 \\
Glutinous rice & 4 \\
Water & 22 \\
\hline Total & 100 \\
\hline
\end{tabular}

\section{김치 제조}

저장된 절임배추는 절단하여 김치 양념과 8:2의 비율로 혼합하여 김치를 제조하였으며, 염도, 산도 및 관능적 특성 을 평가하였다. 대조군으로 Table 1과 같은 배합비로 김치 를 제조하여 $4^{\circ} \mathrm{C}$ 에서 저장하면서 품질 특성을 확인하였다.

\section{염 도}

Blender로 간 반죽상태의 시료 약 $1 \mathrm{~g}$ 을 정확히 달아 적당히 희석(약 100 배)하여 여과(Adventec no. 1)한 후 여과 액 $10 \mathrm{~mL}$ 를 취하고, $2 \%$ potassium chromate $1 \mathrm{~mL}$ 를 넣어 $0.02 \mathrm{~N} \mathrm{AgNO}_{3}$ 용액으로 적정하였다. 별도로 증류수에 대한 바탕시험을 실시하여 다음 식에 따라 계산하였다.

$$
\text { 염도 }(\%)=\frac{(A-B) \times 0.00117 \times f \times D}{S} \times 100
$$
$A$ : 본 시험에 소비된 $0.02 \mathrm{~N} \mathrm{AgNO}_{3}$ 용액의 $\mathrm{mL}$ 수
$B$ : 바탕시험에 소비된 $0.02 \mathrm{~N} \mathrm{AgNO}_{3}$ 용액의 $\mathrm{mL}$ 수
$f: 0.02 \mathrm{~N} \mathrm{AgNO}_{3}$ 용액의 역가
$D$ : 희석배수
$S$ : 시료채취량 $(\mathrm{g})$ 


\section{$\mathrm{pH}$ 및 산도}

시료 단위 무게당 정확한 $\mathrm{pH}$ 나 산도를 측정하기 위하여 다음과 같이 측정하였다. $\mathrm{pH}$ 는 blender로 간 반죽상태의 시료에 $\mathrm{pH}$ electrode를 직접 넣어 측정하였다. 적정산도는 blender로 간 반죽상태의 시료 약 $1 \mathrm{~g}$ 을 정확히 달아 희석 $(100 \mathrm{~mL})$ 하여 여과(HYUNDAI Micro No.10, HYUNDAI Micro., Ltd., Seoul, Korea)한 후 여과액 $20 \mathrm{~mL}$ 에 $0.01 \mathrm{~N}$ $\mathrm{NaOH}$ 용액으로 $\mathrm{pH}$ 가 8.3이 될 때까지 적정하였다. 별도로 증류수에 대한 바탕시험을 실시하여 다음 식에 따라 계산하 였다.

$$
\text { 적정산도 }(\%)=\frac{(A-B) \times 0.0009 \times f \times D}{S} \times 100
$$

$A$ : 본 시험에 소비된 $0.01 \mathrm{~N} \mathrm{NaOH}$ 용액의 $\mathrm{mL}$ 수 $B$ : 바탕시험에 소비된 $0.01 \mathrm{~N} \mathrm{NaOH}$ 용액의 $\mathrm{mL}$ 수 0.0009: $0.01 \mathrm{~N} \mathrm{NaOH} 1 \mathrm{~mL}$ 에 상당하는 lactic $\operatorname{acid}(\mathrm{g})$ $f: 0.01 \mathrm{~N} \mathrm{NaOH}$ 용액의 역가

$D$ : 희석배수

$S$ : 시료채취량 $(\mathrm{g})$

\section{수 분}

수분함량은 blender로 간 반죽상태의 시료 $3 \mathrm{~g}$ 을 취한 후 적외선 수분 측정기(MB45, Ohaus, Boston, $\mathrm{UK})$ 를 이용하여 측정하였다.

\section{미생물 분석}

무균적으로 시료를 $20 \mathrm{~g}$ 취한 후 멸균된 $0.85 \%$ saline용액 으로 10배 희석하여 stomacher(bagmixer R400, Interscience, Saint Nom, France)로 균질화한 후 단계 희석하여 실험을 실시하였다. 일반세균수의 경우 plate count agar(PCA Difco, Franklin Lakes, NJ, USA) 배지를 사용하여 단계별로 희석한 시료를 접종한 후 pouring culture method로 $30^{\circ} \mathrm{C}$ 에 서 48 시간 배양하여 계수하였다. 젖산균의 경우, MRS (Lacto-bacilli MRS Agar, Difco Co., Franklin Lakes, NJ, USA) 배지에 $\mathrm{BCP}($ bromocresol purple) 지시약 $25 \mathrm{ppm}$ 을 넣어 제조한 $\mathrm{BCP}$ 배지를 사용하여 단계별로 희석한 시료를 접종하고 pouring culture method로 $30^{\circ} \mathrm{C}$ 에서 48 시간 배양하 였다. 이 때 노란색을 띄는 colony(유기산 생성균)를 계수하 였다. 효모 및 곰팡이 균수의 경우, PDA(potato dextrose agar, Difco, Franklin Lakes, NJ, USA)배지에 $10 \%$ tartaric acid $1.4 \mathrm{~mL} / 100 \mathrm{~mL}$ 를 첨가하고 단계별로 희석한 시료를 접종한 다음 pouring culture method로 $25^{\circ} \mathrm{C}$ 에서 48 72시간 배양 후 계수하였다. 대장균군은 계수용 $\operatorname{film}(E$. collicoliform Count palte, M Co., St. Paul, MN, USA)에 시료를 접종한 후 $30^{\circ} \mathrm{C}$ 에서 48 시간 배양 후 붉은 집락 중 주위에 기포를 형성하고 있는 집락수를 계수하였다. 계수한 균의 집락 수 는 colony forming unit $(\log \mathrm{CFU} / \mathrm{g})$ 로 표시하였다.

\section{관능적 특성}

관능검사는 훈련된 김치 관능요원 10 명을 선발하여 실시 하였으며 9점 척도법에 따라 매우 강하다는 9점, 아주 강하 다는 8점, 강하다는 7점, 약간 강하다는 6점, 보통이다는 5 점, 약간 약하다는 4점, 약하다는 3점, 아주 약하다는 2점, 매우 약하다는 1점으로 하여 절임배추, 양념, 김치에 대한 선호도를 평가하였다. 절임배추와 김치는 중륵과 잎부분을 양념은 균일하게 혼합하여 약 $20 \mathrm{~g}$ 씩 용기에 담아 제공하였 으며, 관능검사결과는 SPSS program(version 19)을 이용하 여 통계 분석하였다. 절임배추의 평가항목으로는 외관 특 성의 갈색 정도, 밝은 정도, 냄새 특성의 절임배추의 고유의 냄새, 잘 익은 냄새, 과숙된 냄새, 이취, 전체적인 기호도가 있으며 양념의 평가항목으로는 외관 특성의 붉은 정도, 밝 은 정도, 냄새특성의 잘 익은 냄새, 과숙된 냄새, 군덕내, 이취, 맛 특성의 잘 익은 맛, 매운 맛, 짠 맛, 쓴 맛, 과숙된 맛, 이미, 전체적인 기호도가 있으며 김치의 평가항목으로 는 양념의 평가항목에 조직감 특성의 아삭한 정도, 무른 정도, 질긴 정도가 추가하여 분석하였다.

\section{통계분석}

유의성 검증은 IBM SPSS Statistics(19.0, IBM Co., Armonk, NY, USA)을 사용하여 Duncan의 다범위 검정 (Duncan's multiple range test)을 통하여 유의적인 차이를 $\mathrm{p}<0.05$ 수준으로 분석하였다.

\section{결과 및 고찰}

\section{절임배추의 이화학적 품질 특성}

절임배추를 $4^{\circ} \mathrm{C}$ 에서 4 주간 저장하면서 1 주 간격으로 이 화학적 품질 특성을 분석한 결과는 Table 2 및 Fig. 1-3에 나타낸 바와 같다. SKC(salted Kimchi cabbage)-0은 염수에 침지 하지 않은 절임배추이고, SKC- 0.5 는 절임배추 중량 대비 0.5 배의 $2 \%$ 염수에 침지하여 포장한 절임배추이며, SKC-1.0은 절임배추 중량 대비 1.0 배의 $2 \%$ 염수에 침지하 여 포장한 절임배추를 의미한다.

배추의 절임과정은 삼투작용으로 인하여 염수의 소금이 배추 내로 흡수되면서 유해 부패균의 성장을 저지시키는 중요한 과정이다(18). 본 연구에서 절임배추의 초기 염도는 $1.69 \%$ (Table 1)로, 절임배추의 염도가 각각 $1.62 \%, 1.64 \%$ 인 Kim 등(6)과 Park 등(8)의 연구와 비슷한 결과이다. 염수 침지를 하지 않은 절임배추는 저장기간 동안 $1.69 ~ 1.79 \%$ 범위에서 분석되었으며 0 주차에 비하여 2주차에 염도가 다소 증가하였다. 염수 침지한 절임배추는 $1.69 ~ 1.76 \%$ 범 위에서 분석되었으며 0 주차에 비하여 4 주차에 다소 증가하 였는데, 이는 $2 \%$ 염수와 절임배추 사이의 삼투압 현상으로 인해 절임배추의 염도가 다소 증가한 것으로 보인다. 


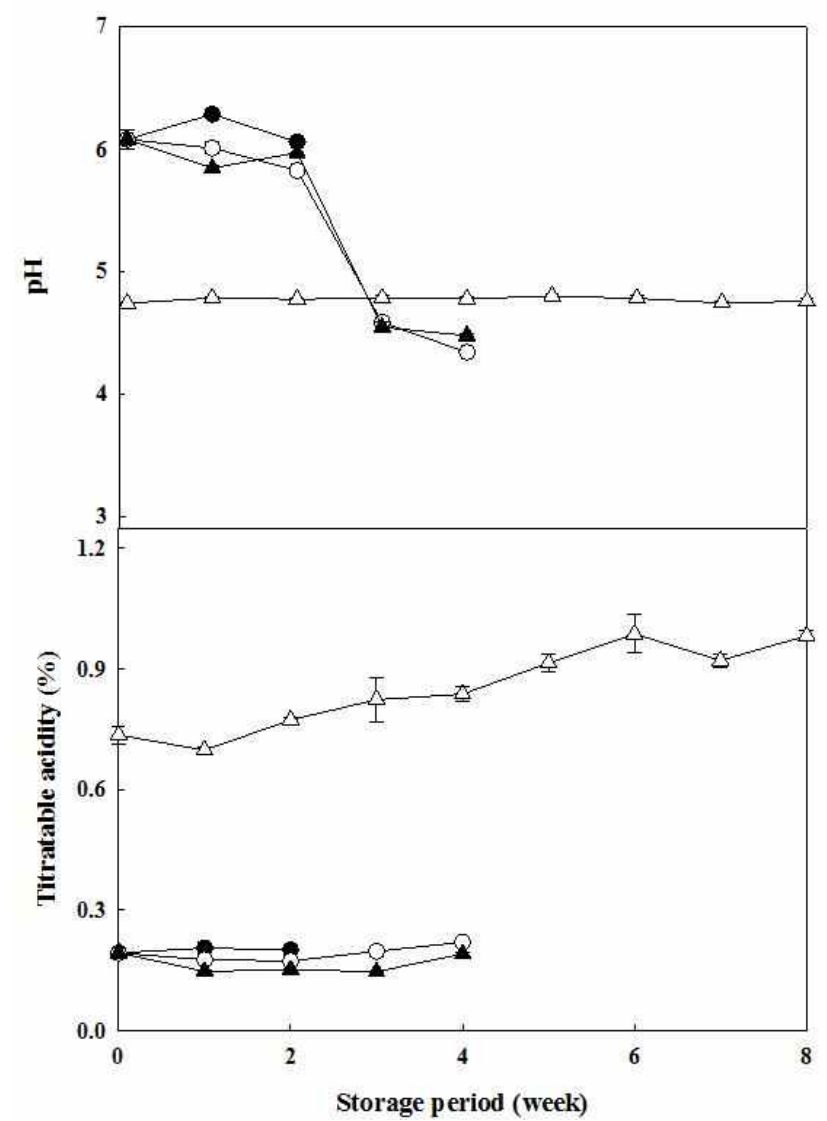

Fig. 1. Changes in $\mathrm{pH}$ and titratable acidity in salted Kimchi cabbage and kimchi paste during storage.

-, SKC-0; - O-, SKC-0.5; - $\mathbf{\Delta}$-, SKC-1.0; - $\triangle$-, kimchi paste.

SKC-0, Salted Kimchi cabbage packed without brine; SKC-0.5 and SKC-1.0, Salted Kimchi cabbage packed with brine ( 0.5 and 1.0 times the weight of salted Kimchi cabbage, respectively).

All values are mean $\pm \mathrm{SD}(\mathrm{n}=3)$

저장기간에 따른 절임배추의 $\mathrm{pH}$ 및 산도의 변화는 Fig. 1 과 같다. 절임배추의 저장 초기 $\mathrm{pH}$ 는 6.08 이였으며, 저장 기간이 경과함에 따라 감소하였다. 일반적으로 절임배추의 $\mathrm{pH}$ 는 저장기간이 경과함에 따라 점차 감소하는 경향을 가 지며(8,20-22), 절임배추의 $\mathrm{pH}$ 가 감소하는 이유는 젖산균 생성에 따른 유기산 생성 때문이다(8). 특히, 절임배추의 $\mathrm{pH}$ 는 저장 2주차까지 약 6.00 수준을 유지하였으나 저장 3 주차에 약 4.5 로 급격히 감소하였다. 본 연구결과는 저장 3 주차에 $\mathrm{pH}$ 가 급격하게 감소되었다는 $\mathrm{Kim}$ 등(6)과 $\mathrm{Han}$ (20)의 보고와도 일치한다. 절임배추의 저장 초기 산도는 $0.19 \%$ 였으며, 이는 절임배추 초기 산도가 약 $0.10 \%$ 라고 보고된 $\mathrm{Kim}$ 등(5)과 Park 등(21)의 연구결과와 비교하였을 때 다소 높게 측정되었음을 알 수 있다. 이는 배추의 품종 및 절임배추 제조방법, 특히 절임 염수농도 차이에 따른 산생성 양의 차이에 의한 것으로 판단된다 $(5,21)$. 염수 침지 를 하지 않은 절임배추는 저장 1 주차에 $0.21 \%$, 절임배추 중량 대비 0.5 배 염수 침지한 절임배추는 저장 3 주차에 $0.20 \%$ 에 도달하였으며, 절임배추 중량 대비 1.0 배 염수 침
Table 2. Changes in salinity of salted Kimchi cabbage and kimchi paste during storage

\begin{tabular}{ccccc}
\hline \multirow{2}{*}{$\begin{array}{c}\text { Storage period } \\
\text { (week) }\end{array}$} & \multicolumn{5}{c}{ Treatment } \\
\cline { 2 - 5 } & SKC-0 $0^{1)}$ & SKC- 0.5 & SKC-1.0 & kimchi paste \\
\hline 0 & $1.69 \pm 0.13^{2) \mathrm{Aab} 3)}$ & $1.69 \pm 0.13^{\mathrm{Aab}}$ & $1.69 \pm 0.13^{\mathrm{Aab}}$ & $3.70 \pm 0.12^{\mathrm{c}}$ \\
1 & $1.60 \pm 0.01^{\mathrm{Ab}}$ & $1.55 \pm 0.06^{\mathrm{Ab}}$ & $1.51 \pm 0.07^{\mathrm{Ac}}$ & $3.80 \pm 0.04^{\mathrm{abc}}$ \\
2 & $1.79 \pm 0.01^{\mathrm{Aa}}$ & $1.60 \pm 0.03^{\mathrm{Bb}}$ & $1.58 \pm 0.00^{\mathrm{Bbc}}$ & $3.89 \pm 0.01^{\mathrm{a}}$ \\
3 & - & $1.56 \pm 0.03^{\mathrm{b}}$ & $1.62 \pm 0.01^{\mathrm{bc}}$ & $3.85 \pm 0.00^{\mathrm{abc}}$ \\
4 & - & $1.76 \pm 0.10^{\mathrm{a}}$ & $1.75 \pm 0.01^{\mathrm{a}}$ & $3.73 \pm 0.09^{\mathrm{bc}}$ \\
5 & - & - & - & $3.71 \pm 0.12^{\mathrm{c}}$ \\
6 & - & - & - & $3.87 \pm 0.06^{\mathrm{ab}}$ \\
7 & - & - & - & $3.86 \pm 0.11^{\mathrm{abc}}$ \\
8 & - & - & - & $3.93 \pm 0.05^{\mathrm{a}}$ \\
\hline
\end{tabular}

${ }^{1)}$ SKC-0, Salted Kimchi cabbage packed without brine; SKC-0.5 and SKC-1.0, Salted Kimchi cabbage packed with brine ( 0.5 and 1.0 times the weight of salted Kimchi cabbage, respectively).

${ }^{2)}$ All values are mean $\pm \mathrm{SD}$.

${ }^{33}$ Any means in the same row (A-B) or column (a-c) followed by different letters are significantly $(\mathrm{p}<0.05)$ different by Duncan's multiple range test.

지한 절임배추는 저장 4 주차에도 저장 초기와 같은 $0.19 \%$ 를 유지하였다. 또한, 절임배추 중량 대비 1.0 배의 염수를 포장한 절임배추의 산도는 절임배추 중량 대비 0.5 배의 염 수를 넣어 포장한 절임배추보다 저장기간 동안 항상 낮게 측정되었다. 즉, 염수 침지하여 포장한 절임배추는 염수 침지하지 않은 절임배추보다 절임배추의 발효를 적당한 상태로 유지시키거나 지연시키며 특히, 절임배추 중량 대 비 1.0 배의 염수에 침지시키면 더욱 효과적이라고 판단된 다.

저장기간에 따른 절임배추의 수분함량 변화는 Fig. 2 와

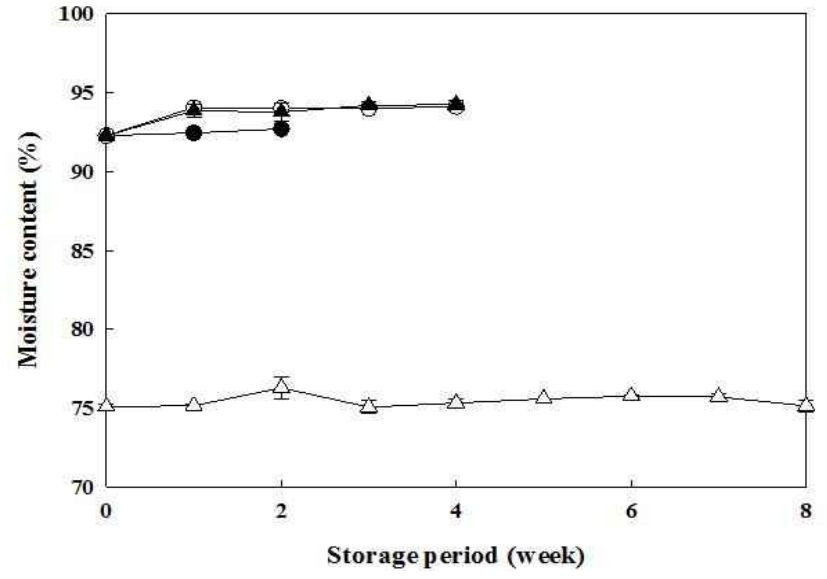

Fig. 2. Changes in moisture content in salted Kimchi cabbage and kimchi paste during storage.

SKC-0; - O-, SKC-0.5; - $\boldsymbol{\Delta}$-, SKC-1.0; - $\triangle$-, kimchi paste.

SKC-0, Salted Kimchi cabbage packed without brine; SKC-0.5 and SKC-1.0, Salted Kimchi cabbage packed with brine ( 0.5 and 1.0 times the weight of salted Kimchi cabbage respectively)

All values are mean \pm SD $(n=3)$. 
같다. 저장 초기 절임배추의 수분함량은 $92.28 \%$ 였으며, $10 \%$ 염수에 18 시간 절인 절임배추의 수분함량이 약 $92 \%$ 라 고 보고된 $\operatorname{Hwang}(22)$ 의 연구결과와 일치하였다. 염수 침지 를 하지 않은 절임배추는 저장 2주차까지 $92.70 \%$ 로 초기와 비슷한 수분함량을 나타내었으나, 염수 침지한 절임배추의 수분함량은 저장기간이 경과함에 따라 점차 증가하였고 저장 1 주차부터는 염수 침지를 하지 않은 절임배추와 유의 적인 차이 $(\mathrm{p}<0.05)$ 를 보였다. 즉, $2 \%$ 염수를 침지한 절임배 추는 염수를 침지하지 않은 절임배추보다 수분함량이 높음 을 알 수 있었다. 이는 염수에 침지하여 포장한 절임배추에

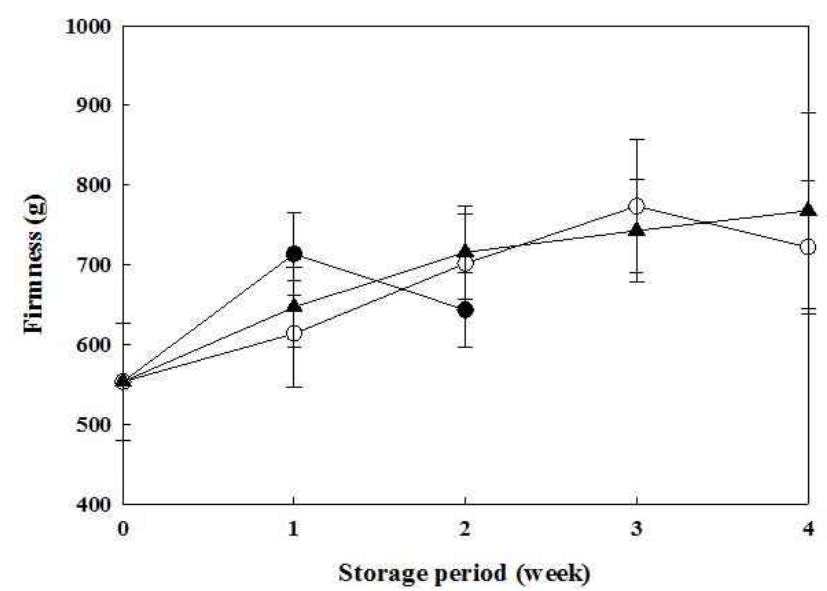

Fig. 3. Changes in firmness in salted Kimchi cabbage during storage.

-, SKC-0; - O-, SKC-0.5; - $\boldsymbol{\Delta}$-, SKC-1.0; - $\triangle$-, kimchi paste.

SKC-0, Salted Kimchi cabbage packed without brine; SKC-0.5 and SKC-1.0, Salted Kimchi cabbage packed with brine ( 0.5 and 1.0 times the weight of salted Kimchi cabbage respectively).

All values are mean $\pm \mathrm{SD}(\mathrm{n}=3)$
침투된 염수의 수분이 완전히 제거되지 않아 수분함량이 높게 측정되었을 것이라 사료된다.

저장기간에 따른 절임배추의 경도 변화는 Fig. 3과 같다. 절임배추의 초기 경도는 $553 \mathrm{~g}$ 로 분석되었으며, 이는 절임 배추 초기 경도가 $595 \mathrm{~g}$ 라고 보고된 Lee 등(23)의 연구결과 와 유사하게 확인되었다. 염수 침지를 하지 않은 절임배추 의 경도는 1 주차까지는 증가하였으나 2 주차에는 감소하였 다. 저장 중 절임배추의 조직감이 감소하는 주된 이유는 절임배추의 조직연화의 진행 때문이며, 이는 절임배추 조 직의 세포내 수분손실 및 미생물에 의한 부패에 의한 것으 로 알려져 있다 $(8,24)$. 본 연구에서 염수에 침지하지 않은 절임배추는 저장 1주차부터 갈변진행(Fig. 4), 미생물 성장 (Table 3) 등의 변화가 일어났으며, 이러한 영향으로 저장 2주차에 경도가 감소되었을 것이라 사료된다. 반면, 염수에 침지한 절임배추의 경도는 저장기간이 경과할수록 점차 증가하는 경향을 보였으며, 염수 중량에 따른 유의적 차이 는 보이지 않았다. 염수 침지한 절임배추는 염수와 절임배 추 간의 삼투압 작용으로 인하여 절임배추 세포 내부의 수분이 용출됨에 따라 세포벽이 겹쳐져 경도가 증가하였을 것으로 판단된다(25).

\section{양념의 이화학적 품질 특성 변화}

김치 양념을 $4{ }^{\circ} \mathrm{C}$ 에서 8 주간 저장하면서 1 주 간격으로 이화학적 품질 특성을 분석한 결과를 Table 2 및 Fig. 1 2에 나타내었다.

양념의 초기 염도(Table 2)는 $3.70 \%$ 이었으며, 저장 기간 동안 3.70 3.93\% 범위에서 비슷한 수준으로 분석되었다. 양념의 $\mathrm{pH}$ 및 산도를 측정한 결과(Fig. 1$), \mathrm{pH}$ 는 저장기간

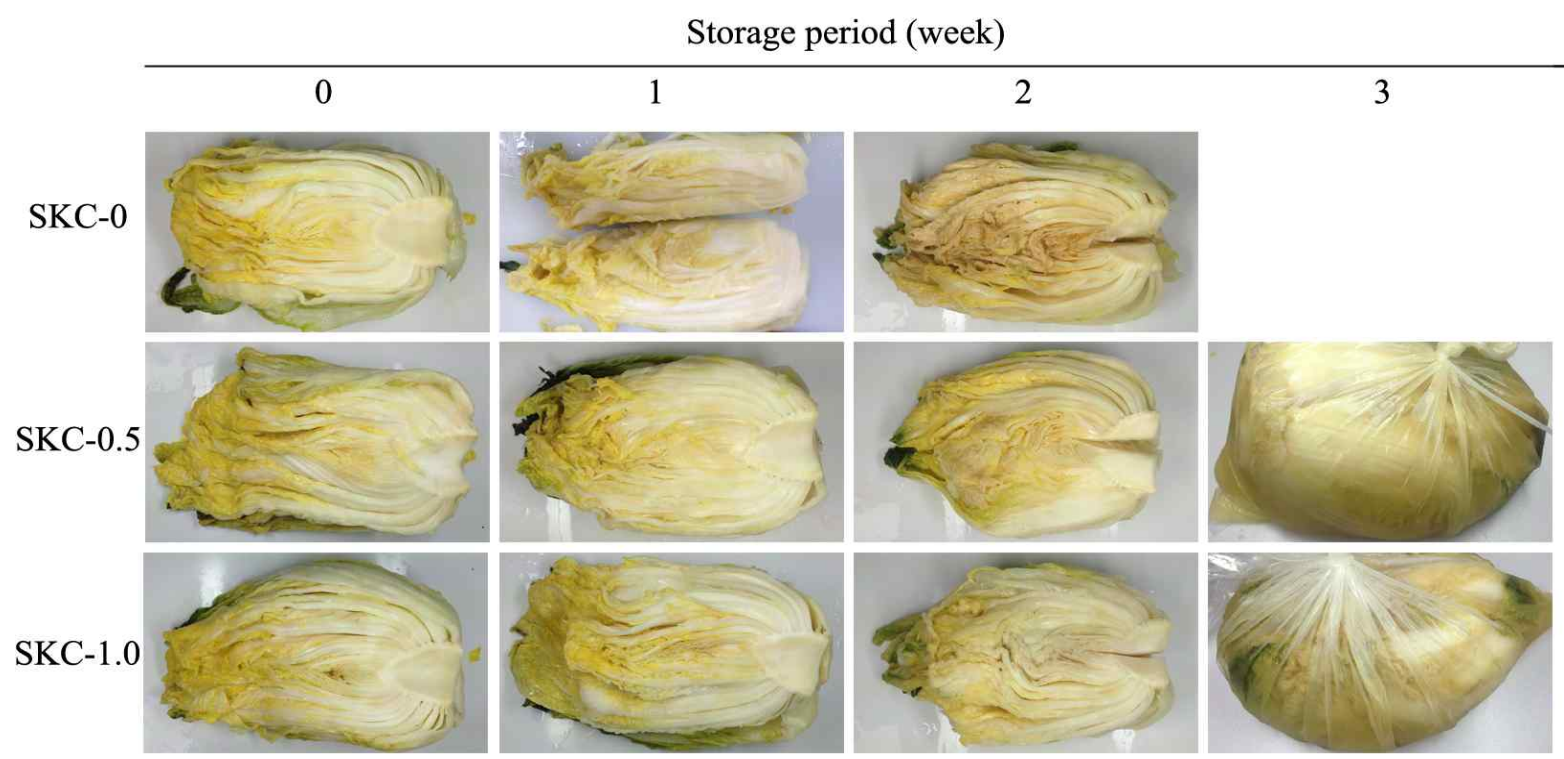

Fig. 4. Changes in appearance of salted Kimchi cabbage during storage.

SKC-0, Salted Kimchi cabbage packed without brine; SKC- 0.5 and SKC-1.0, Salted Kimchi cabbage packed with brine (0.5 and 1.0 times the weight of salted Kimchi cabbage respectively). 
Table 3. Changes in microorganisms of salted Kimchi cabbage during storage

\begin{tabular}{|c|c|c|c|c|c|c|}
\hline \multirow{2}{*}{$\begin{array}{l}\text { Microorganisms } \\
(\log \mathrm{CFU} / \mathrm{g})\end{array}$} & \multirow{2}{*}{ Treatment } & \multicolumn{5}{|c|}{ Storage period (week) } \\
\hline & & 0 & 1 & 2 & 3 & 4 \\
\hline \multirow{3}{*}{ Aerobic plate count } & SKC-0 $0^{1)}$ & $5.36 \pm 0.00^{2) \mathrm{Ac} 33}$ & $6.66 \pm 0.05^{\mathrm{Bb}}$ & $7.59 \pm 0.12^{\mathrm{Aa}}$ & & \\
\hline & SKC- 0.5 & $5.36 \pm 0.00^{\mathrm{Ae}}$ & $6.91 \pm 0.06^{\mathrm{Ad}}$ & $7.30 \pm 0.00^{\mathrm{Bc}}$ & $7.48 \pm 0.04^{b}$ & $8.85 \pm 0.02^{\mathrm{a}}$ \\
\hline & SKC-1.0 & $5.36 \pm 0.00^{\mathrm{Ae}}$ & $6.29 \pm 0.08^{\mathrm{Cd}}$ & $7.03 \pm 0.06^{\mathrm{Cc}}$ & $7.18 \pm 0.02^{\mathrm{b}}$ & $8.21 \pm 0.01^{\mathrm{a}}$ \\
\hline \multirow{3}{*}{ Lactic acid bacteria } & SKC-0 & $4.18 \pm 0.01^{\mathrm{Ac}}$ & $5.39 \pm 0.12^{\mathrm{Bb}}$ & $6.40 \pm 0.08^{\mathrm{Ca}}$ & & \\
\hline & SKC- 0.5 & $4.18 \pm 0.01^{\mathrm{Ae}}$ & $6.25 \pm 0.0 .2^{\mathrm{Ad}}$ & $7.22 \pm 0.11^{\mathrm{Ac}}$ & $7.47 \pm 0.05^{\mathrm{b}}$ & $8.82 \pm 0.04^{\mathrm{a}}$ \\
\hline & SKC-1.0 & $4.18 \pm 0.01^{\mathrm{Ae}}$ & $5.41 \pm 0.00^{\mathrm{Bd}}$ & $6.72 \pm 0.00^{\mathrm{Bc}}$ & $7.22 \pm 0.00^{\mathrm{b}}$ & $8.16 \pm 0.00^{\mathrm{a}}$ \\
\hline \multirow{3}{*}{ Yeast and molds } & SKC-0 & $\mathrm{ND}^{4)}$ & $3.44 \pm 0.09^{\mathrm{a}}$ & $2.76 \pm 0.11^{\mathrm{Bb}}$ & & \\
\hline & SKC-0.5 & $\mathrm{ND}$ & $\mathrm{ND}$ & $1.80 \pm 0.14^{\mathrm{Ab}}$ & $1.54 \pm 0.09^{\mathrm{c}}$ & $2.96 \pm 0.01^{\mathrm{a}}$ \\
\hline & SKC-1.0 & ND & $2.15 \pm 0.15 b$ & $2.12 \pm 0.12^{\mathrm{Bb}}$ & ND & $2.93 \pm 0.03^{\mathrm{a}}$ \\
\hline \multirow{3}{*}{ Coliform group } & SKC-0 & $5.03 \pm 0.01 \mathrm{Ac}$ & $6.02 \pm 0.03 \mathrm{Ab}$ & $6.73 \pm 0.02^{\mathrm{Aa}}$ & & \\
\hline & SKC-0.5 & $5.03 \pm 0.01 \mathrm{Ac}$ & $5.50 \pm 0.28 \mathrm{Ab}$ & $6.16 \pm 0.06^{\mathrm{Ba}}$ & $5.78 \pm 0.01^{b}$ & $4.76 \pm 0.11^{\mathrm{c}}$ \\
\hline & SKC-1.0 & $5.03 \pm 0.01 \mathrm{Ad}$ & $5.99 \pm 0.12 \mathrm{Ab}$ & $6.67 \pm 0.01^{\mathrm{Aa}}$ & $5.64 \pm 0.07^{\mathrm{c}}$ & $5.20 \pm 0.17^{\mathrm{d}}$ \\
\hline
\end{tabular}

${ }^{1)}$ SKC-0, Salted Kimchi cabbage packed without brine; SKC-0.5 and SKC-1.0, Salted Kimchi cabbage packed with brine (0.5 and 1.0 times the weight of salted Kimchi cabbage, respectively).

${ }^{2)}$ All values are mean $\pm \mathrm{SD}$.

${ }^{33}$ Any means in the same row $(\mathrm{A}-\mathrm{C})$ or column $(\mathrm{a}-\mathrm{e})$ followed by different letters are significantly $(\mathrm{p}<0.05)$ different by Duncan's multiple range test.

${ }^{4} \mathrm{ND}$, Not detected.

동안 4.74 4.78의 비슷한 수준의 범위에서 분석되었으 며, 이는 김치속의 초기 $\mathrm{pH}$ 가 약 5.0 이라고 보고된 Park 등(12)과 Choi 등(17)의 연구결과와 비슷하다. 저장기간 동 안 양념의 $\mathrm{pH}$ 는 비슷한 수준을 유지하였으며, 이는 Park 등(12)의 연구결과와 일치하였다. 본 연구결과는 저장기간 이 경과함에 따라 $\mathrm{pH}$ 가 감소하였다는 Choi 등(17)과 Yun 등(26)의 연구결과와는 다르게 나타나 양념 조성이 $\mathrm{pH}$ 에 영향을 미친 것으로 생각된다. 양념의 산도는 저장 초기 $0.74 \%$ 에서 저장 8 주차에 $0.98 \%$ 로 점차 증가하는 경향을 보이며 이는 저장기간이 경과함에 따라 김치속의 산도가 증가한다는 Choi 등(17)의 연구결과와 일치한다. Park 등 (12), Choi 등(17), Yun 등(26)의 양념의 초기 산도가 약 $0.2 \%$ 라고 보고된 결과와 비교하였을 때 본 연구 결과는 다소 높은 값을 나타내었으며, 이는 양념을 구성하는 재료 의 품질 차이에 의한 것으로 판단된다. 또한 양념의 수분함 량은 저장 8 주 동안 $75.05 ~ 76.28 \%$ 의 범위에서 분석되었다 (Fig. 2).

\section{절임배추의 미생물학적 품질 특성}

절임배추의 저장 중 일반세균, 젖산균, 효모 및 곰팡이, 대장균군, 대장균 수의 변화는 Table 3 과 같다. 절임배추의 초기 일반세균수는 $5.36 \log \mathrm{CFU} / \mathrm{g}$ 이며, Park 등(8)의 연구 결과와 일치한다. 일반적으로 절임배추의 일반세균수는 저 장기간이 경과함에 따라 증가하는 경향을 보이며 $(5,27)$, 본 연구에서도 점차 증가하는 경향을 보였다. 저장 2 주차에 염수 침지하지 않은 절임배추는 염수 침지한 절임배추에
비하여 유의적으로 높은 값을 나타내었다 $(\mathrm{p}<0.05)$. 또한, 저장 기간 동안 염수 중량이 적은 절임배추의 일반세균수가 높게 검출되었다. 즉, $2 \%$ 염수를 침지하여 저장하는 방법은 절임배추의 일반세균의 증식을 지연시켜 주며, 특히 염수 중량이 많을수록 더욱 지연시킬 수 있음을 알 수 있었다. 절임배추의 젖산균수는 일반세균수와 마찬가지로 저장 기 간이 경과할수록 점차 증가하는 패턴을 보이며, 초기 젖산 균수는 $4.18 \log \mathrm{CFU} / \mathrm{g}$ 로 분석되었다. 일반세균수의 처리구 간의 패턴과는 반대로, 염수 침지한 절임배추가 염수 침지 하지 않은 절임배추보다 높게 분석되었으며, 이는 아마도 염수에 의하여 공기가 차단되어 통성혐기성균인 젖산균수 가 증가하였기 때문이라 판단된다. 효모 및 곰팡이는 저장 초기에는 검출되지 않았으나, 저장기간이 경과함에 따라 검출되었다. 대장균군은 저장 초기 $5.03 \log \mathrm{CFU} / \mathrm{g}$ 이었으 며, 저장 2 주차까지는 증가하나 그 이후로는 감소하는 경향 을 보였다. 대장균은 저장 기간 동안 모든 처리구에서 검출 되지 않았다.

\section{양념의 미생물학적 품질 특성}

양념의 저장 중 미생물학적 품질 특성 변화는 Table 4 와 같다. 양념의 일반세균수는 저장기간 동안 $6.17 \sim 6.48 \mathrm{log}$ $\mathrm{CFU} / \mathrm{g}$ 범위에서 분석되었으며, 젖산균수는 저장 초기에 $6.71 \log \mathrm{CFU} / \mathrm{g}$ 이었으나 저장 8 주차에는 $4.61 \log \mathrm{CFU} / \mathrm{g}$ 으로 저장기간이 경과함에 따라 유의적인 차이 $(\mathrm{p}<0.05)$ 를 보이며 감소하였다. 효모 및 곰팡이와 대장균은 저장 8 주 동안 모든 처리구에서 검출되지 않았다. 대장균군은 저장 
Table 4. Changes in microorganisms of kimchi paste during storage

\begin{tabular}{ccccc}
\hline \multirow{2}{*}{$\begin{array}{c}\text { Storage period } \\
\text { (week) }\end{array}$} & $\begin{array}{c}\text { Merobic plate } \\
\text { count }\end{array}$ & $\begin{array}{c}\text { Lactic acid } \\
\text { bacteria }\end{array}$ & $\begin{array}{c}\text { Yeast and } \\
\text { molds }\end{array}$ & $\begin{array}{c}\text { Coliform } \\
\text { group }\end{array}$ \\
\cline { 2 - 5 } & $6.40 \pm 0.05^{1 \mathrm{lab} 2)}$ & $6.71 \pm 0.04^{\mathrm{a}}$ & $\mathrm{ND}^{3)}$ & $4.31 \pm 0.08$ \\
1 & $6.48 \pm 0.12^{\mathrm{a}}$ & $6.00 \pm 0.01^{\mathrm{b}}$ & $\mathrm{ND}$ & $2.48 \pm 0.00$ \\
2 & $6.19 \pm 0.04^{\mathrm{c}}$ & $5.98 \pm 0.05^{\mathrm{b}}$ & $\mathrm{ND}$ & $\mathrm{ND}$ \\
3 & $6.17 \pm 0.02^{\mathrm{c}}$ & $5.95 \pm 0.05^{\mathrm{b}}$ & $\mathrm{ND}$ & $\mathrm{ND}$ \\
4 & $6.25 \pm 0.07^{\mathrm{b}}$ & $5.55 \pm 0.06^{\mathrm{c}}$ & $\mathrm{ND}$ & $\mathrm{ND}$ \\
5 & $6.48 \pm 0.12^{\mathrm{a}}$ & $5.62 \pm 0.07^{\mathrm{c}}$ & $\mathrm{ND}$ & $\mathrm{ND}$ \\
6 & $6.21 \pm 0.01^{\mathrm{c}}$ & $5.02 \pm 0.00^{\mathrm{d}}$ & $\mathrm{ND}$ & $\mathrm{ND}$ \\
7 & $6.43 \pm 0.02^{\mathrm{a}}$ & $4.99 \pm 0.02^{\mathrm{d}}$ & $\mathrm{ND}$ & $\mathrm{ND}$ \\
8 & $6.40 \pm 0.06^{\mathrm{ab}}$ & $4.61 \pm 0.01^{\mathrm{e}}$ & $\mathrm{ND}$ & $\mathrm{ND}$ \\
\hline
\end{tabular}

${ }^{11)}$ All values are mean $\pm \mathrm{SD}$.

${ }^{2)}$ Any means in the same column (a-e) followed by different letters are significantly $(\mathrm{p}<0.05)$ different by Duncan's multiple range test.

${ }^{3} \mathrm{ND}$, Not detected.

초기에 $4.31 \log \mathrm{CFU} / \mathrm{g}$ 이었으나 발효됨에 따라 점차 감소 하여 저장 3 주차부터는 검출되지 않았다. 스타터 및 멸치액 젓을 첨가한 양념은 숙성됨에 따라 대장균군이 사멸한다고
보고한 Choi 등(17)의 연구와 일치한다. 또한, 대장균은 저 장 기간 동안 모든 처리구에서 검출되지 않았다.

\section{절임배추 및 양념의 관능적 품질 특성}

절임배추 및 양념의 저장기간에 따른 관능적 품질 특성 을 평가한 결과는 Table 5 및 6과 같다. 외관 특성인 절임배 추의 갈색 정도는 저장기간이 경과함에 따라 유의적인 차이 ( $\mathrm{p}<0.05)$ 를 보이며 증가하였다. 저장 1 주차부터 염수 침지 하지 않은 절임배추는 염수 침지한 절임배추에 비해 유의적 으로 높은 점수를 받았다. 절임배추의 밝은 정도는 저장기 간이 경과함에 따라 유의적인 차이를 보이며 감소하였다. 저장 1 주차부터 염수 침지를 하지 않은 절임배추는 염수 침지한 절임배추보다 유의적으로 낮은 점수를 받았다. 특 히, 저장 2 주차의 염수 침지 하지 않은 절임배추는 저장 4 주차 염수 침지한 절임배추보다 낮은 점수를 받았다. 이절 된 절임배추의 외관(Fig. 4)을 보면, 염수 침지하지 않은 절임배추는 저장 1 주차부터 갈변이 시작되었으며 저장 2 주 차에는 갈변 정도가 심하여 상품으로서의 가치가 없어지게 되었다. 염수 침지한 절임배추는 저장 2 주차부터 갈변이 시작되었으며, 저장 3주차에 갈변 정도는 5 6점 정도로 점수는 낮았으나 염수의 갈변이 진행되어 상품으로서의

Table 5. Changes in sensory properties of salted Kimchi cabbage during storage

\begin{tabular}{|c|c|c|c|c|c|c|c|}
\hline & & \multirow{2}{*}{ Treatment } & \multicolumn{5}{|c|}{ Storage period (week) } \\
\hline & & & 0 & 1 & 2 & 3 & 4 \\
\hline \multirow{6}{*}{ Appearance } & \multirow{3}{*}{ Browning degree } & SKC- $0^{1)}$ & $1.40 \pm 0.52^{2 \mathrm{~A} A \mathrm{~s} 3}$ & $5.11 \pm 1.17^{\mathrm{Ab}}$ & $7.10 \pm 0.88^{\mathrm{Aa}}$ & & \\
\hline & & SKC- 0.5 & $1.40 \pm 0.52^{\mathrm{Ac}}$ & $3.50 \pm 1.58^{\mathrm{Bb}}$ & $4.90 \pm 1.45^{\mathrm{Bab}}$ & $6.33 \pm 1.00^{\mathrm{a}}$ & $6.38 \pm 1.19^{\mathrm{a}}$ \\
\hline & & SKC-1.0 & $1.40 \pm 0.52^{\mathrm{Ac}}$ & $3.50 \pm 1.27^{\mathrm{Bb}}$ & $4.67 \pm 1.32^{\mathrm{Bab}}$ & $5.22 \pm 1.09^{\mathrm{a}}$ & $5.75 \pm 1.91^{\mathrm{a}}$ \\
\hline & \multirow{3}{*}{ Lightening degree } & SKC-0.0 & $7.90 \pm 1.52^{\mathrm{Aa}}$ & $5.11 \pm 1.45^{\mathrm{Bb}}$ & $3.75 \pm 0.71^{\mathrm{Bc}}$ & & \\
\hline & & SKC-0.5 & $7.90 \pm 1.52^{\mathrm{Aa}}$ & $6.50 \pm 1.27^{\mathrm{Ab}}$ & $5.44 \pm 1.13^{\mathrm{Ab}}$ & $4.11 \pm 0.93^{\mathrm{c}}$ & $3.89 \pm 1.36^{\mathrm{c}}$ \\
\hline & & SKC-1.0 & $7.90 \pm 1.52^{\mathrm{Aa}}$ & $6.60 \pm 1.17^{\mathrm{Aab}}$ & $5.30 \pm 1.34^{\mathrm{Abc}}$ & $4.78 \pm 1.48^{\mathrm{c}}$ & $4.13 \pm 1.46^{c}$ \\
\hline \multirow{9}{*}{ Flavor } & \multirow{3}{*}{$\begin{array}{l}\text { Salted Kimchi cabbage } \\
\text { flavor }\end{array}$} & SKC-0 & $5.50 \pm 0.97^{\mathrm{Aa}}$ & $5.10 \pm 1.60^{\mathrm{Aa}}$ & $3.75 \pm 0.71^{\mathrm{Bb}}$ & & \\
\hline & & SKC-0.5 & $5.50 \pm 0.97^{\mathrm{Aa}}$ & $5.60 \pm 1.65^{\mathrm{Aa}}$ & $5.20 \pm 1.55^{\mathrm{Aa}}$ & $5.13 \pm 0.64^{\mathrm{a}}$ & $5.11 \pm 2.09^{\mathrm{a}}$ \\
\hline & & SKC-1.0 & $5.50 \pm 0.97^{\mathrm{Aa}}$ & $5.70 \pm 0.95^{\mathrm{Aa}}$ & $5.20 \pm 1.14^{\mathrm{Aa}}$ & $5.78 \pm 0.83^{\mathrm{a}}$ & $4.56 \pm 2.07^{\mathrm{a}}$ \\
\hline & \multirow{3}{*}{ Ripening flavor } & SKC-0 & $2.30 \pm 1.25^{\mathrm{Ab}}$ & $3.78 \pm 1.99^{\mathrm{Ab}}$ & $5.50 \pm 1.90^{\mathrm{Aa}}$ & & \\
\hline & & SKC- 0.5 & $2.30 \pm 1.25^{\mathrm{Ac}}$ & $4.10 \pm 1.91^{\mathrm{Ab}}$ & $5.30 \pm 1.64^{\mathrm{Aab}}$ & $5.44 \pm 1.24^{\mathrm{ab}}$ & $5.75 \pm 1.58^{\mathrm{a}}$ \\
\hline & & SKC-1.0 & $2.30 \pm 1.25^{\mathrm{Ac}}$ & $4.20 \pm 1.93^{\mathrm{Ab}}$ & $4.70 \pm 0.82^{\mathrm{Aab}}$ & $6.00 \pm 0.87^{\mathrm{a}}$ & $5.63 \pm 1.51^{\mathrm{a}}$ \\
\hline & \multirow{3}{*}{ Off-flavor } & SKC-0 & $1.60 \pm 0.70^{\mathrm{Ac}}$ & $3.20 \pm 1.23^{\mathrm{Ab}}$ & $6.50 \pm 1.18^{\mathrm{Aa}}$ & & \\
\hline & & SKC- 0.5 & $1.60 \pm 0.70^{\mathrm{Ad}}$ & $3.10 \pm 1.91^{\mathrm{Ac}}$ & $5.50 \pm 0.97^{\mathrm{ABb}}$ & $5.33 \pm 1.22^{\mathrm{b}}$ & $6.83 \pm 1.33^{\mathrm{a}}$ \\
\hline & & SKC-1.0 & $1.60 \pm 0.70^{\mathrm{Ac}}$ & $2.70 \pm 1.16^{\mathrm{Ac}}$ & $4.63 \pm 1.41^{\mathrm{Bb}}$ & $5.00 \pm 1.07^{\mathrm{ab}}$ & $6.00 \pm 1.41^{\mathrm{a}}$ \\
\hline \multirow{3}{*}{\multicolumn{2}{|c|}{ Overall preference }} & SKC-0 & $5.71 \pm 0.76^{\mathrm{Aa}}$ & $4.71 \pm 1.11^{\mathrm{Aa}}$ & $2.86 \pm 0.90^{\mathrm{Bb}}$ & & \\
\hline & & SKC- 0.5 & $5.71 \pm 0.76^{\mathrm{Aa}}$ & $5.50 \pm 0.93^{\mathrm{ABa}}$ & $4.75 \pm 0.50^{\mathrm{Aab}}$ & $4.00 \pm 1.20^{\mathrm{bc}}$ & $2.88 \pm 1.25^{\mathrm{c}}$ \\
\hline & & SKC-1.0 & $5.71 \pm 0.76^{\mathrm{Aab}}$ & $5.88 \pm 0.64^{\mathrm{Bab}}$ & $6.00 \pm 0.89^{\mathrm{Aa}}$ & $4.75 \pm 1.04^{b}$ & $3.43 \pm 1.51^{\mathrm{c}}$ \\
\hline
\end{tabular}

${ }^{1)}$ SKC-0, Salted Kimchi cabbage packed without brine; SKC-0.5 and SKC-1.0, Salted Kimchi cabbage packed with brine (0.5 and 1.0 times the weight of salted Kimchi cabbage, respectively).

${ }^{2)}$ All values are mean $\pm \mathrm{SD}$

${ }^{3)}$ Any means in the same row $(\mathrm{A}-\mathrm{B})$ or column $(\mathrm{a}-\mathrm{e})$ followed by different letters are significantly $(\mathrm{p}<0.05)$ different by Duncan's multiple range test. 
Table 6. Changes in sensory properties of kimchi paste during storage

\begin{tabular}{|c|c|c|c|c|c|c|c|c|c|c|}
\hline & & \multicolumn{9}{|c|}{ Storage period (week) } \\
\hline & & 0 & 1 & 2 & 3 & 4 & 5 & 6 & 7 & 8 \\
\hline \multirow{2}{*}{ Appearance } & Redness degree & $7.40 \pm 1.07^{\left.1)_{2} 2\right)}$ & $6.70 \pm 0.95^{\mathrm{ab}}$ & $7.20 \pm 1.32^{\mathrm{ab}}$ & $6.00 \pm 0.53^{\mathrm{ab}}$ & $6.44 \pm 1.33^{\mathrm{b}}$ & $6.60 \pm 0.84^{\mathrm{ab}}$ & $6.30 \pm 1.42^{\mathrm{ab}}$ & $6.70 \pm 0.95^{\mathrm{ab}}$ & $6.20 \pm 1.69^{\mathrm{ab}}$ \\
\hline & Lightening degree & $3.70 \pm 1.16^{\mathrm{a}}$ & $3.50 \pm 1.27^{\mathrm{a}}$ & $3.70 \pm 1.25^{\mathrm{a}}$ & $4.44 \pm 1.24^{\mathrm{a}}$ & $4.44 \pm 1.13^{\mathrm{a}}$ & $4.10 \pm 0.99^{\mathrm{a}}$ & $4.20 \pm 1.48^{\mathrm{a}}$ & $3.80 \pm 1.23^{\mathrm{a}}$ & $4.70 \pm 1.49^{\mathrm{a}}$ \\
\hline \multirow{4}{*}{ Flavor } & Ripening flavor & $3.40 \pm 1.84^{b}$ & $5.38 \pm 2.07^{\mathrm{a}}$ & $5.00 \pm 1.83^{\mathrm{a}}$ & $5.78 \pm 1.20^{\mathrm{a}}$ & $5.89 \pm 1.45^{\mathrm{a}}$ & $5.89 \pm 1.54^{\mathrm{a}}$ & $6.25 \pm 1.28^{\mathrm{a}}$ & $6.20 \pm 1.69^{\mathrm{a}}$ & $6.40 \pm 1.84^{\mathrm{a}}$ \\
\hline & Overripened flavor & $2.80 \pm 1.62^{\mathrm{c}}$ & $3.88 \pm 1.64^{\mathrm{bc}}$ & $4.30 \pm 1.70^{\mathrm{abc}}$ & $4.56 \pm 1.88^{\mathrm{ab}}$ & $4.89 \pm 1.69^{\mathrm{ab}}$ & $5.30 \pm 1.44^{\mathrm{ab}}$ & $5.29 \pm 1.38^{\mathrm{ab}}$ & $5.88 \pm 1.89^{\mathrm{a}}$ & $5.70 \pm 1.83^{\mathrm{ab}}$ \\
\hline & Moldy flavor & $2.30 \pm 1.25^{\mathrm{c}}$ & $2.70 \pm 1.95^{\mathrm{bc}}$ & $3.60 \pm 1.58^{\mathrm{abc}}$ & $3.56 \pm 1.67^{\mathrm{abc}}$ & $4.13 \pm 1.36^{\mathrm{ab}}$ & $4.20 \pm 1.48^{\mathrm{ab}}$ & $4.60 \pm 1.51^{\mathrm{a}}$ & $4.88 \pm 0.99^{\mathrm{a}}$ & $5.00 \pm 1.25^{\mathrm{a}}$ \\
\hline & Off-flavor & $2.40 \pm 1.35^{\mathrm{b}}$ & $2.40 \pm 1.26^{\mathrm{b}}$ & $3.75 \pm 1.75^{\mathrm{ab}}$ & $3.22 \pm 1.30^{\mathrm{ab}}$ & $3.89 \pm 1.45^{\mathrm{ab}}$ & $4.20 \pm 1.48^{\mathrm{a}}$ & $4.10 \pm 1.29^{\mathrm{a}}$ & $3.60 \pm 1.96^{\mathrm{ab}}$ & $4.00 \pm 1.49^{\mathrm{a}}$ \\
\hline \multirow{6}{*}{ Taste } & Ripped taste & $3.20 \pm 1.35^{\mathrm{c}}$ & $4.30 \pm 1.70^{\mathrm{bc}}$ & $4.80 \pm 1.87^{\mathrm{ab}}$ & $5.56 \pm 1.01^{\mathrm{ab}}$ & $4.78 \pm 1.09^{\mathrm{ab}}$ & $5.30 \pm 1.57^{\mathrm{ab}}$ & $5.10 \pm 1.73^{\mathrm{ab}}$ & $6.10 \pm 1.29^{\mathrm{a}}$ & $5.60 \pm 1.51^{\mathrm{ab}}$ \\
\hline & Pungency & $6.10 \pm 1.10^{\mathrm{ab}}$ & $6.60 \pm 0.70^{\mathrm{a}}$ & $6.10 \pm 1.60^{\mathrm{ab}}$ & $5.78 \pm 0.83^{\mathrm{ab}}$ & $6.11 \pm 0.93^{\mathrm{ab}}$ & $5.40 \pm 0.70^{b}$ & $6.00 \pm 0.67^{\mathrm{ab}}$ & $5.70 \pm 1.16^{\mathrm{ab}}$ & $5.90 \pm 1.29^{\mathrm{ab}}$ \\
\hline & Saltness & $5.20 \pm 1.23^{\mathrm{a}}$ & $5.40 \pm 1.07^{\mathrm{a}}$ & $5.10 \pm 0.88^{\mathrm{a}}$ & $4.89 \pm 1.36^{\mathrm{a}}$ & $5.00 \pm 1.00^{\mathrm{a}}$ & $5.20 \pm 0.92^{\mathrm{a}}$ & $5.10 \pm 1.10^{\mathrm{a}}$ & $4.80 \pm 1.14^{\mathrm{a}}$ & $5.00 \pm 1.25^{\mathrm{a}}$ \\
\hline & Bitterness & $3.25 \pm 1.67^{b}$ & $3.00 \pm 1.15^{\mathrm{ab}}$ & $3.80 \pm 1.48^{\mathrm{ab}}$ & $3.89 \pm 1.45^{\mathrm{ab}}$ & $4.33 \pm 1.32^{\mathrm{ab}}$ & $4.20 \pm 1.32^{\mathrm{ab}}$ & $4.50 \pm 1.18^{\mathrm{a}}$ & $4.25 \pm 1.28^{\mathrm{ab}}$ & $4.50 \pm 1.65^{\mathrm{a}}$ \\
\hline & Overripened taste & $3.20 \pm 1.48^{\mathrm{bc}}$ & $2.90 \pm 1.45^{\mathrm{c}}$ & $3.63 \pm 1.19^{\mathrm{abc}}$ & $4.29 \pm 1.89^{\mathrm{abc}}$ & $4.00 \pm 1.58^{\mathrm{abc}}$ & $5.20 \pm 1.23^{\mathrm{a}}$ & $4.60 \pm 1.43^{\mathrm{ab}}$ & $5.00 \pm 1.69^{\mathrm{a}}$ & $5.10 \pm 1.66^{\mathrm{ab}}$ \\
\hline & Off-taste & $2.70 \pm 1.34^{\mathrm{b}}$ & $3.10 \pm 1.29^{\mathrm{ab}}$ & $3.40 \pm 1.26^{\mathrm{ab}}$ & $3.11 \pm 1.27^{\mathrm{ab}}$ & $3.33 \pm 1.58^{\mathrm{ab}}$ & $4.30 \pm 1.42^{\mathrm{a}}$ & $4.20 \pm 1.23^{\mathrm{a}}$ & $3.63 \pm 1.41^{\mathrm{ab}}$ & $3.70 \pm 1.42^{\mathrm{ab}}$ \\
\hline \multicolumn{2}{|c|}{ Overall preference } & $5.60 \pm 1.26^{\mathrm{ab}}$ & $6.00 \pm 1.33^{\mathrm{ab}}$ & $6.10 \pm 1.10^{\mathrm{a}}$ & $5.56 \pm 0.73^{\mathrm{ab}}$ & $5.22 \pm 1.30^{\mathrm{ab}}$ & $5.40 \pm 1.17^{\mathrm{ab}}$ & $4.90 \pm 0.99^{b}$ & $5.50 \pm 1.08^{\mathrm{ab}}$ & $5.60 \pm 0.97^{\mathrm{ab}}$ \\
\hline
\end{tabular}

${ }^{11}$ All values are mean $\pm \mathrm{SD}$.

${ }^{2)}$ Any means in the same row $(a-c)$ followed by different letters are significantly $(\mathrm{p}<0.05)$ different by Duncan's multiple range test.

가치가 없어지게 되었다. 따라서 염수 침지를 하지 않은 절임배추의 저장한계는 1 주 이내이며, 염수 침지한 절임배 추의 저장한계는 2 주 이내로 판단된다. 또한, 염수 침지 포장은 절임배추의 갈변 정도와 밝은 정도의 변화를 지연시 켜 준다고 판단된다. 냄새 특성인 잘 익은 냄새와 이취는 저장기간이 경과함에 따라 유의적인 차이를 보이며 증가하 였으며 처리구간의 유의적인 차이를 보이지 않았다. 전체 적인 기호도는 저장기간 동안 염수 침지한 절임배추가 유의 적으로 높은 점수를 받았으며, 염수중량이 많을수록 더 높 은 점수를 받았다.

저장 기간 중 양념의 관능적 품질 특성(Table 6) 결과, 저장기간이 경과함에 따라 냄새, 잘익은 맛 점수는 증가하 였으며 전체적인 기호도는 4.90 6.10 수준의 점수를 유지하 며 증가 혹은 감소하였다. 따라서 양념의 저장한계는 8 주 정도로 판단되어진다.

Table 7. Changes in salinity of kimchi during storage

\begin{tabular}{ccccc}
\hline \multirow{2}{*}{ Treatment } & \multicolumn{4}{c}{ Storage period (week) } \\
\cline { 2 - 5 } & 0 & 1 & 2 & 3 \\
\hline Kimchi-C ${ }^{1)}$ & $2.02 \pm 0.06^{2) \mathrm{Ab} 3)}$ & $2.11 \pm 0.01^{\mathrm{Ab}}$ & $2.35 \pm 0.07^{\mathrm{Aa}}$ & $2.06 \pm 0.02^{\mathrm{ABb}}$ \\
Kimchi-0 & $2.02 \pm 0.06^{\mathrm{A}}$ & $2.10 \pm 0.01^{\mathrm{A}^{*}}$ & & \\
Kimchi-0.5 & $2.02 \pm 0.06^{\mathrm{Abc}}$ & $1.95 \pm 0.06^{\mathrm{Bc}}$ & $2.19 \pm 0.04^{\mathrm{Ba}}$ & $2.08 \pm 0.06^{\mathrm{Aab}}$ \\
Kimchi- $1.0^{2.00} \pm 0.06^{\mathrm{Aa}}$ & $1.81 \pm 0.01^{\mathrm{Cb}}$ & $2.07 \pm 0.07^{\mathrm{Ba}}$ & $2.00 \pm 0.01^{\mathrm{Ba}}$ \\
\hline
\end{tabular}

${ }^{1)}$ Kimchi-C, prepared at 0 day; Kimchi-0, 0.5, and 1.0, prepared with stored kimchi paste and salted Kimchi cabbage (SKC-0, 0.5, and 1.0, respectively) at every week ${ }^{2)}$ All values are mean $\pm \mathrm{SD}$.

${ }^{3)}$ Any means in the same row (A-C) or column (a-c) followed by different letters are significantly $(\mathrm{p}<0.05)$ different by Duncan's multiple range test.

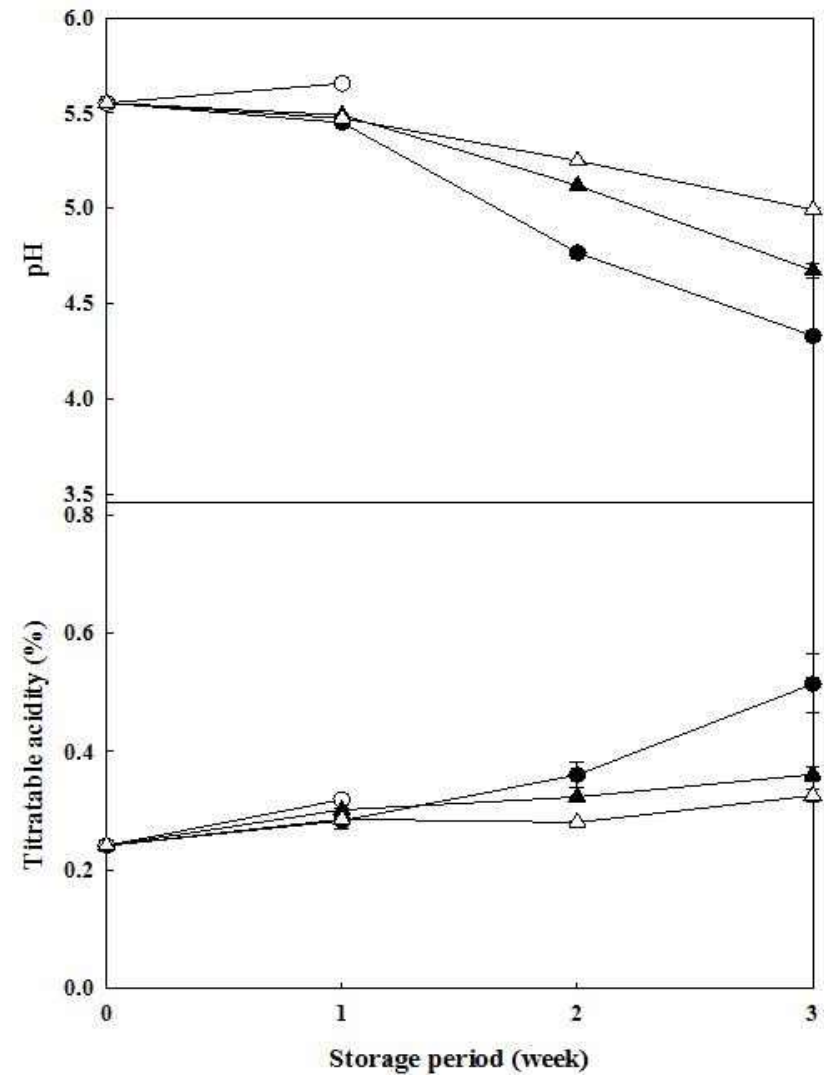

Fig. 5. Changes in $\mathrm{pH}$ and titratable acidity in kimchi during storage.

-, SKC-0; - O-, SKC-0.5; - $\mathbf{\Delta}$-, SKC-1.0; - $\triangle$-, kimchi paste. Kimchi-1.0. Kimchi-C, prepared at 0 day; Kimchi-0, 0.5 , and 1.0 , prepared with stored kimchi paste and salted Kimchi cabbage (SKC-0, 0.5 , and 1.0, respectively) at every week.

All values are mean $\pm \mathrm{SD}(\mathrm{n}=3)$. 
Table 8. Changes in sensory properties of kimchi during storage (9-point hedonic scale)

\begin{tabular}{|c|c|c|c|c|c|c|}
\hline & & \multirow{2}{*}{ Treatment } & \multicolumn{4}{|c|}{ Storage period (week) } \\
\hline & & & 0 & 1 & 2 & 3 \\
\hline \multirow{8}{*}{ Appearance } & \multirow{4}{*}{ Redness degree } & Kimchi-C $C^{1)}$ & $4.90 \pm 1.10^{2 \mathrm{AA} a 3)}$ & $5.50 \pm 1.43^{\mathrm{Aa}}$ & $4.80 \pm 1.23^{\mathrm{Aa}}$ & $4.89 \pm 1.69^{\mathrm{Aa}}$ \\
\hline & & Kimchi-0 & $4.90 \pm 1.10^{\mathrm{A}}$ & $4.80 \pm 1.40^{\mathrm{A}}$ & & \\
\hline & & Kimchi-0.5 & $4.90 \pm 1.10^{\mathrm{Aa}}$ & $5.20 \pm 0.92^{\mathrm{Aa}}$ & $4.90 \pm 1.60^{\mathrm{Aa}}$ & $5.00 \pm 1.00^{\mathrm{Aa}}$ \\
\hline & & Kimchi-1.0 & $4.90 \pm 1.10^{\mathrm{Aa}}$ & $4.80 \pm 1.48^{\mathrm{Aa}}$ & $4.70 \pm 0.82^{\mathrm{Aa}}$ & $4.89 \pm 1.05^{\mathrm{Aa}}$ \\
\hline & \multirow{4}{*}{ Lightening degree } & Kimchi-C & $6.50 \pm 1.18^{\mathrm{Aa}}$ & $4.80 \pm 1.48^{\mathrm{Ab}}$ & $4.80 \pm 1.55^{\mathrm{Ab}}$ & $4.00 \pm 0.87^{\mathrm{Bb}}$ \\
\hline & & Kimchi-0 & $6.50 \pm 1.18^{\mathrm{A}}$ & $5.30 \pm 1.06^{\mathrm{A}}$ & & \\
\hline & & Kimchi-0.5 & $6.50 \pm 1.18^{\mathrm{Aa}}$ & $4.50 \pm 0.97^{\mathrm{Ab}}$ & $5.70 \pm 1.42^{\mathrm{Aa}}$ & $5.56 \pm 0.53^{\mathrm{Aa}}$ \\
\hline & & Kimchi-1.0 & $6.50 \pm 1.18^{\mathrm{Aa}}$ & $4.80 \pm 0.79^{\mathrm{Ab}}$ & $5.80 \pm 0.79^{\mathrm{Aa}}$ & $5.78 \pm 0.97^{\mathrm{Aa}}$ \\
\hline \multirow{16}{*}{ Flavor } & \multirow{4}{*}{ Ripening flavor } & Kimchi-C & $3.40 \pm 1.71^{\mathrm{Ac}}$ & $4.40 \pm 1.65^{\mathrm{Abc}}$ & $5.60 \pm 1.34^{\mathrm{Aab}}$ & $6.44 \pm 1.13^{\mathrm{Aa}}$ \\
\hline & & Kimchi-0 & $3.40 \pm 1.71^{\mathrm{A}}$ & $4.40 \pm 1.71^{\mathrm{A}}$ & & \\
\hline & & Kimchi-0.5 & $3.40 \pm 1.71^{\mathrm{Ab}}$ & $3.60 \pm 1.07^{\mathrm{Ab}}$ & $4.20 \pm 1.40^{\mathrm{Bab}}$ & $5.33 \pm 1.00^{\mathrm{Ba}}$ \\
\hline & & Kimchi-1.0 & $3.40 \pm 1.71^{\mathrm{Ac}}$ & $3.60 \pm 1.26^{\mathrm{Abc}}$ & $4.80 \pm 1.32^{\mathrm{ABab}}$ & $5.33 \pm 1.00^{\mathrm{Ba}}$ \\
\hline & \multirow{4}{*}{ Overripened flavor } & Kimchi-C & $2.50 \pm 1.08^{\mathrm{Ac}}$ & $3.13 \pm 1.13^{\mathrm{Ac}}$ & $4.70 \pm 1.25^{\mathrm{Ab}}$ & $6.00 \pm 1.50^{\mathrm{Ba}}$ \\
\hline & & Kimchi-0 & $2.50 \pm 1.08^{\mathrm{A}}$ & $2.90 \pm 1.60^{\mathrm{A}}$ & & \\
\hline & & Kimchi-0.5 & $2.50 \pm 1.08^{\mathrm{Ab}}$ & $2.80 \pm 1.14^{\mathrm{Ab}}$ & $3.70 \pm 1.57^{\mathrm{Aab}}$ & $4.44 \pm 1.42^{\mathrm{Aa}}$ \\
\hline & & Kimchi-1.0 & $2.50 \pm 1.08^{\mathrm{Ab}}$ & $2.90 \pm 1.37^{\mathrm{Ab}}$ & $3.70 \pm 1.42^{\mathrm{Aab}}$ & $4.56 \pm 1.59^{\mathrm{ABa}}$ \\
\hline & \multirow{4}{*}{ Moldy flavor } & Kimchi-C & $2.10 \pm 0.88^{\mathrm{Ac}}$ & $2.90 \pm 1.37^{\mathrm{Abc}}$ & $4.10 \pm 1.79^{\mathrm{Aab}}$ & $4.89 \pm 1.83^{\mathrm{Aa}}$ \\
\hline & & Kimchi-0 & $2.10 \pm 0.88^{\mathrm{A}}$ & $2.80 \pm 1.81^{\mathrm{A}}$ & & \\
\hline & & Kimchi-0.5 & $2.10 \pm 0.88^{\mathrm{Ab}}$ & $3.20 \pm 1.48^{\mathrm{Ab}}$ & $3.30 \pm 1.06^{\mathrm{Aab}}$ & $4.44 \pm 1.51^{\mathrm{Aa}}$ \\
\hline & & Kimchi-1.0 & $2.10 \pm 0.88^{\mathrm{Ab}}$ & $3.40 \pm 1.90^{\mathrm{Aab}}$ & $3.30 \pm 1.25^{\mathrm{Ab}}$ & $4.67 \pm 1.41^{\mathrm{Aa}}$ \\
\hline & \multirow{4}{*}{ Off flavor } & Kimchi-C & $2.10 \pm 0.88^{\mathrm{Ab}}$ & $3.30 \pm 1.77^{\mathrm{Aab}}$ & $3.70 \pm 1.89^{\mathrm{Aa}}$ & $4.22 \pm 1.56^{\mathrm{Aa}}$ \\
\hline & & Kimchi-0 & $2.10 \pm 0.88^{\mathrm{A}}$ & $3.20 \pm 1.62^{\mathrm{A}}$ & & \\
\hline & & Kimchi- 0.5 & $2.10 \pm 0.88^{\mathrm{Ab}}$ & $3.00 \pm 0.94^{\mathrm{Ab}}$ & $3.00 \pm 1.25^{\mathrm{Ab}}$ & $4.67 \pm 1.58^{\mathrm{Aa}}$ \\
\hline & & Kimchi-1.0 & $2.10 \pm 0.88^{\mathrm{b}}$ & $3.40 \pm 1.43^{\text {Aab }}$ & $3.60 \pm 1.71^{\mathrm{Aa}}$ & $4.33 \pm 1.32^{\mathrm{Aa}}$ \\
\hline \multirow{24}{*}{ Taste } & \multirow{4}{*}{ Ripened taste } & Kimchi-C & $2.50 \pm 0.97^{\mathrm{Ac}}$ & $3.30 \pm 1.83^{\mathrm{Ac}}$ & $4.80 \pm 1.32 \mathrm{Ab}$ & $6.33 \pm 1.58^{\mathrm{Aa}}$ \\
\hline & & Kimchi-0 & $2.50 \pm 0.97^{\mathrm{A}}$ & $2.40 \pm 1.43^{\mathrm{A}}$ & & \\
\hline & & Kimchi-0.5 & $2.50 \pm 0.97^{\mathrm{Ab}}$ & $3.00 \pm 1.56^{\mathrm{Ab}}$ & $3.60 \pm 1.58^{\mathrm{Aab}}$ & $4.56 \pm 1.67^{\mathrm{Ba}}$ \\
\hline & & Kimchi-1.0 & $2.50 \pm 0.97^{\mathrm{Ab}}$ & $2.80 \pm 1.75^{\mathrm{Ab}}$ & $3.60 \pm 1.35^{\mathrm{Aab}}$ & $4.33 \pm 1.32^{\mathrm{Ba}}$ \\
\hline & \multirow{4}{*}{ Pungency } & Kimchi-C & $4.90 \pm 1.73^{\mathrm{Aa}}$ & $5.40 \pm 1.07^{\mathrm{Aa}}$ & $5.10 \pm 1.20^{\mathrm{Aa}}$ & $5.22 \pm 1.09^{\mathrm{Aa}}$ \\
\hline & & Kimchi-0 & $4.90 \pm 1.73^{\mathrm{A}}$ & $4.80 \pm 1.62^{\mathrm{A}}$ & & \\
\hline & & Kimchi-0.5 & $4.90 \pm 1.73^{\mathrm{Aa}}$ & $5.20 \pm 0.92^{\mathrm{Aa}}$ & $4.70 \pm 1.64^{\mathrm{Aa}}$ & $5.00 \pm 1.22^{\mathrm{Aa}}$ \\
\hline & & Kimchi-1.0 & $4.90 \pm 1.73^{\mathrm{Aa}}$ & $5.20 \pm 1.03^{\mathrm{Aa}}$ & $5.30 \pm 1.49^{\mathrm{Aa}}$ & $4.67 \pm 1.32^{\mathrm{Aa}}$ \\
\hline & \multirow{4}{*}{ Saltness } & Kimchi-C & $5.50 \pm 1.43^{\mathrm{Aa}}$ & $5.40 \pm 1.17^{\mathrm{Aa}}$ & $5.70 \pm 0.95^{\mathrm{Aa}}$ & $5.67 \pm 1.12^{\mathrm{Aa}}$ \\
\hline & & Kimchi-0 & $5.50 \pm 1.43^{\mathrm{A}}$ & $5.90 \pm 1.20^{\mathrm{A}}$ & & \\
\hline & & Kimchi-0.5 & $5.50 \pm 1.43^{\mathrm{Aa}}$ & $5.70 \pm 1.64^{\mathrm{Aa}}$ & $5.20 \pm 0.79^{\mathrm{Aa}}$ & $6.44 \pm 1.88^{\mathrm{Aa}}$ \\
\hline & & Kimchi-1.0 & $5.50 \pm 1.43^{\mathrm{Aa}}$ & $5.90 \pm 1.20^{\mathrm{Aa}}$ & $5.60 \pm 1.43^{\mathrm{Aa}}$ & $6.00 \pm 1.22^{\mathrm{A}}$ \\
\hline & \multirow{4}{*}{ Bitterness } & Kimchi-C & $2.90 \pm 1.45^{\mathrm{Ab}}$ & $3.90 \pm 1.52^{\mathrm{Aab}}$ & $4.40 \pm 2.07^{\mathrm{Aab}}$ & $5.00 \pm 1.00^{\mathrm{Aa}}$ \\
\hline & & Kimchi-0 & $2.90 \pm 1.45^{\mathrm{A}}$ & $4.10 \pm 1.91^{\mathrm{A}}$ & & \\
\hline & & Kimchi-0.5 & $2.90 \pm 1.45^{\mathrm{Ab}}$ & $3.70 \pm 1.77^{\mathrm{Ab}}$ & $4.30 \pm 1.49^{\mathrm{Aab}}$ & $5.44 \pm 1.59^{\mathrm{Aa}}$ \\
\hline & & Kimchi-1.0 & $2.90 \pm 1.45^{\mathrm{Ab}}$ & $4.00 \pm 1.89^{\mathrm{Aab}}$ & $3.80 \pm 1.62^{\text {Aab }}$ & $5.33 \pm 1.32^{\mathrm{Aa}}$ \\
\hline & \multirow{4}{*}{ Overripened taste } & Kimchi-C & $2.44 \pm 1.24^{\mathrm{Ab}}$ & $2.40 \pm 1.17^{\mathrm{Ab}}$ & $5.30 \pm 1.95 \mathrm{~A}^{\mathrm{a}}$ & $5.67 \pm 1.41^{\mathrm{Aa}}$ \\
\hline & & Kimchi-0 & $2.44 \pm 1.24^{\mathrm{A}}$ & $2.20 \pm 1.23^{\mathrm{A}}$ & & \\
\hline & & Kimchi-0.5 & $2.44 \pm 1.24^{\mathrm{Ab}}$ & $2.50 \pm 1.08^{\mathrm{Ab}}$ & $3.80 \pm 1.99^{\mathrm{Aab}}$ & $4.22 \pm 1.48^{\mathrm{Ba}}$ \\
\hline & & Kimchi-1.0 & $2.44 \pm 1.24^{\mathrm{Ab}}$ & $2.60 \pm 1.35^{\mathrm{Ab}}$ & $3.20 \pm 1.40^{\mathrm{Aab}}$ & $4.00 \pm 1.12^{\mathrm{Ba}}$ \\
\hline & \multirow{4}{*}{ Off taste } & Kimchi-C & $2.30 \pm 0.95^{\mathrm{Ab}}$ & $3.00 \pm 1.56^{A} b$ & $3.63 \pm 1.77^{\mathrm{Ab}}$ & $4.67 \pm 1.58^{\mathrm{Aa}}$ \\
\hline & & Kimchi-0 & $2.30 \pm 0.95^{\mathrm{A}}$ & $3.00 \pm 0.94^{\mathrm{A}}$ & & \\
\hline & & Kimchi-0.5 & $2.30 \pm 0.95^{\mathrm{Ab}}$ & $3.30 \pm 1.42^{\mathrm{Ab}}$ & $3.30 \pm 1.77^{\mathrm{Ab}}$ & $5.00 \pm 1.80^{\mathrm{Aa}}$ \\
\hline & & Kimchi-1.0 & $2.30 \pm 0.95^{\mathrm{Ab}}$ & $3.60 \pm 1.71^{\mathrm{Aab}}$ & $3.00 \pm 1.25^{\mathrm{Ab}}$ & $4.56 \pm 2.07^{\mathrm{Aa}}$ \\
\hline
\end{tabular}

${ }^{1}$ Kimchi-C, prepared at 0 day; Kimchi-0, 0.5, and 1.0, prepared with stored kimchi paste and salted Kimchi cabbage (SKC-0, 0.5, and 1.0, respectively) at every week.

${ }^{2)}$ All values are mean $\pm \mathrm{SD}$.

${ }^{3)}$ Any means in the same row $(\mathrm{A}-\mathrm{B})$ or column $(\mathrm{a}-\mathrm{c})$ followed by different letters are significantly $(\mathrm{p}<0.05)$ different by Duncan's multiple range test. 
Table 8. Continued

\begin{tabular}{|c|c|c|c|c|c|c|}
\hline & & \multirow{2}{*}{ Treatment } & \multicolumn{4}{|c|}{ Storage period (week) } \\
\hline & & & 0 & 1 & 2 & 3 \\
\hline \multirow{12}{*}{ Texture } & \multirow{4}{*}{ Crispiness } & Kimchi-C & $6.70 \pm 1.34^{\mathrm{Aa}}$ & $5.80 \pm 1.23^{\mathrm{ABab}}$ & $5.30 \pm 0.95^{\mathrm{Ab}}$ & $5.22 \pm 1.09^{\mathrm{Ab}}$ \\
\hline & & Kimchi-0 & $6.70 \pm 1.34^{\mathrm{A}}$ & $6.70 \pm 1.16^{\mathrm{A}}$ & & \\
\hline & & Kimchi- 0.5 & $6.70 \pm 1.34^{\mathrm{Aa}}$ & $5.80 \pm 0.73^{\mathrm{ABa}}$ & $6.00 \pm 1.05^{\mathrm{Aa}}$ & $6.33 \pm 0.71^{\mathrm{Aa}}$ \\
\hline & & Kimchi-1.0 & $6.70 \pm 1.34^{\mathrm{Ab}}$ & $5.40 \pm 0.97^{\mathrm{Bab}}$ & $5.80 \pm 1.23^{\mathrm{Ab}}$ & $6.33 \pm 1.58^{\mathrm{Aa}}$ \\
\hline & \multirow{4}{*}{ Softness } & Kimchi-C & $3.30 \pm 1.42^{\mathrm{Ab}}$ & $4.10 \pm 1.60^{\mathrm{Aab}}$ & $5.10 \pm 0.99^{\mathrm{Aa}}$ & $5.33 \pm 1.41^{\mathrm{Aa}}$ \\
\hline & & Kimchi-0 & $3.30 \pm 1.42^{\mathrm{A}}$ & $3.40 \pm 1.26^{\mathrm{A}}$ & & \\
\hline & & Kimchi- 0.5 & $3.30 \pm 1.42^{\mathrm{Aa}}$ & $4.00 \pm 1.56^{\mathrm{Aa}}$ & $4.30 \pm 1.16^{\mathrm{Aa}}$ & $4.22 \pm 1.09^{\mathrm{ABa}}$ \\
\hline & & Kimchi-1.0 & $3.30 \pm 1.42^{\mathrm{Ab}}$ & $4.10 \pm 1.37^{\mathrm{Aab}}$ & $4.70 \pm 1.42^{\mathrm{Ab}}$ & $3.78 \pm 1.30^{\mathrm{Ba}} b$ \\
\hline & \multirow{4}{*}{ Toughness } & Kimchi-C & $3.10 \pm 1.66^{\mathrm{Ac}}$ & $4.10 \pm 1.29^{\mathrm{Abc}}$ & $4.50 \pm 1.43^{\mathrm{Aab}}$ & $5.56 \pm 1.01^{\mathrm{Aa}}$ \\
\hline & & Kimchi-0 & $3.10 \pm 1.66^{\mathrm{A}}$ & $3.60 \pm 1.17^{\mathrm{A}}$ & & \\
\hline & & Kimchi- 0.5 & $3.10 \pm 1.66^{\mathrm{Ac}}$ & $3.80 \pm 1.23^{\mathrm{Abc}}$ & $4.70 \pm 1.25^{\mathrm{Aab}}$ & $5.44 \pm 1.74^{\mathrm{Aa}}$ \\
\hline & & Kimchi-1.0 & $3.10 \pm 1.66^{\mathrm{Ab}}$ & $4.10 \pm 0.99^{\mathrm{Aab}}$ & $4.20 \pm 1.62^{\mathrm{Aab}}$ & $4.78 \pm 1.39^{\mathrm{Aa}}$ \\
\hline \multirow{4}{*}{\multicolumn{2}{|c|}{ Overall preference }} & Kimchi-C & $5.70 \pm 1.70^{\mathrm{Aa}}$ & $3.90 \pm 1.60^{\mathrm{Ab}}$ & $4.20 \pm 1.62^{\mathrm{Ab}}$ & $5.11 \pm 0.78^{\mathrm{Aab}}$ \\
\hline & & Kimchi-0 & $5.70 \pm 1.70^{\mathrm{A}}$ & $4.30 \pm 1.64^{\mathrm{A}}$ & & \\
\hline & & Kimchi- 0.5 & $5.70 \pm 1.70^{\mathrm{Aa}}$ & $4.60 \pm 1.17^{\mathrm{Aa}}$ & $4.80 \pm 1.62^{\mathrm{Aa}}$ & $4.78 \pm 1.20^{\mathrm{Aa}}$ \\
\hline & & Kimchi-1.0 & $5.70 \pm 1.70^{\mathrm{Aa}}$ & $4.00 \pm 1.41^{\mathrm{Ab}}$ & $4.80 \pm 1.87^{\mathrm{Aab}}$ & $5.00 \pm 1.00^{\mathrm{Aab}}$ \\
\hline
\end{tabular}

${ }^{1)}$ Kimchi-C, prepared at 0 day; Kimchi-0, 0.5, and 1.0, prepared with stored kimchi paste and salted Kimchi cabbage (SKC-0, 0.5, and 1.0, respectively) at every week.

${ }^{2)}$ All values are mean $\pm \mathrm{SD}$.

${ }^{3)}$ Any means in the same row $(\mathrm{A}-\mathrm{B})$ or column $(\mathrm{a}-\mathrm{c})$ followed by different letters are significantly $(\mathrm{p}<0.05)$ different by Duncan's multiple range test.

\section{김치의 이화학적 품질 특성}

저장된 절임배추와 양념을 이용하여 매주 김치를 제조하 여 $4^{\circ} \mathrm{C}$ 에서 8 주간 저장하면서 1 주 간격으로 김치의 이화학 적 및 관능적 품질특성을 분석한 결과 특성을 비교하여 관찰한 결과를 Table 7 및 Fig. 5에 나타내었다. 김치 -C(Kimchi-C)는 0주차에 제조된 절임배추와 양념으로 만든 김치이고, 김치-0(Kimchi-0)는 염수 침지를 하지 않은 저장 된 절임배추와 저장된 양념으로 매주 제조한 김치이고, 김 치-0.5(Kimchi-0.5)은 절임배추 중량 대비 0.5 배의 염수 침 지한 저장된 절임배추와 저장된 양념으로 매주 제조한 김치 이고, 김치-1.0(Kimchi-1.0)는 절임배추 중량 대비 1.0 배의 염수 침지한 저장된 절임배추와 저장된 양념으로 매주 제조 한 김치이다. 김치 -0 은 염수 침지를 하지 않은 절임배추의 저장한계가 1 주 이내이므로 1 주까지 실험을 진행하였으며, 김치 -0.5 와 김치 -1.0 는 염수 침지를 한 절임배추의 저장한 계가 2주 이내이므로 2 주까지 실험을 진행하였다.

저장 기간 중 김치의 염도는 $1.80 ~ 2.19 \%$ 범위에서 분석 되었으며(Table 7), 염수 침지한 절임배추로 제조된 김치의 염도는 염수 침지하지 않은 절임배추로 제조된 김치보다 낮았다. 이는 염수에 침지된 절임배추는 일정시간(1시간) 탈수하여 실험에 사용하였는데, 절임배추의 수분함량이 높 게 측정된 것으로 미루어 볼때 초기에 김치로 제조된 절임 배추와 탈수율이 동일하지 않아 나타난 결과라 생각된다.
따라서 상대적으로 절임배추의 염도도 낮게 측정이 되고 결과적으로 최종 김치염도에도 영향을 미쳐 염수에 침지하 지 않은 절임배추로 제조한 김치 보다 염수에 침지한 절임 배추로 제조한 김치에서 염도가 낮게 측정된 것으로 사료 된다.

김치는 일반적으로 저장기간이 경과함에 따라 숙성이 진행되면서 $\mathrm{pH}$ 는 감소하고 산도는 증가하는 경향을 보이 며(28-30), 본 연구결과도 같은 경향을 보인다(Fig. 5). 김치 의 초기 $\mathrm{pH}$ 와 산도는 각각 $5.55,0.24 \%$ 로 분석되었으며 Choi 등(31)의 연구결과와 유사하게 나타났다. 저장 3 주 동안, 김치 3 및 4 는 김치 1 에 비하여 $\mathrm{pH}$ 는 높게 산도는 낮게 분석되었다. 즉, 절임배추와 양념을 각각 따로 저장한 후 제조한 김치는 절임배추와 양념을 이용하여 제조하여 저장한 김치보다 숙성이 지연되는 것으로 확인되었다.

\section{김치의 관능적 품질 특성}

저장 기간 중 김치의 관능적 품질특성을 Table 8에 나타 내었다. 관능적 품질특성인 외관, 냄새, 맛, 조직감, 전체적 기호도 모든 항목에서 처리구 간의 유의적인 차이가 없었 다. 즉, 절임배추와 양념을 이용하여 저장한 김치와 절임배 추와 양념을 각각 따로 저장하여 제조한 김치는 $\mathrm{pH}$ 및 산도 와 같은 이화학적 품질 지표에서는 차이는 나지만(Fig. 5) 관능적으로는 차이가 없는 것으로 나타났다. 


\section{요 약}

절임배추와 양념으로 구성된 제품에 대한 품질 특성 정 보를 제고하고, 버무린 형태로 저장된 김치와 절임배추와 양념을 분리 저장한 후 버무린 김치의 품질 특성의 차이를 확인하기 위해 $4^{\circ} \mathrm{C}$ 에서 저장하면서 1 주 간격으로 품질특성 을 분석하였다. 절임배추의 산도 및 일반세균수 변화 결과, 염수 침지에 따른 절임배추의 품질유지 효과가 나타났으 며, 외관 및 관능적 품질 특성 결과를 토대로 염수 침지하지 않은 절임배추의 저장한계는 1 주, 염수침지한 절임배추의 저장한계는 2 주 이내임을 알 수 있었다. 특히, 염수량이 많을수록 품질 유지에 더욱 효과적이었으며 관능적 특성에 서도 다소 높은 점수를 받았다. 양념은 저장 8 주 동안 산도 가 증가하는 경향을 보였으나 미생물학적 및 관능적 품질 특성에는 큰 변화가 없었다. 0 일차에 제조하여 $4^{\circ} \mathrm{C}$ 에서 저 장한 김치와 $4{ }^{\circ} \mathrm{C}$ 에서 각각 저장된 절임배추와 양념을 이용 하여 매주 제조한 김치의 품질 특성을 분석한 결과, 0 일차에 제조하여 저장한 김치보다 저장된 절임배추와 양념으로 매주 제조한 김치의 $\mathrm{pH}$ 가 높고, 산도가 낮아 발효 지연 효과가 있는 것으로 나타났다. 특히 3 주차 저장된 절임배추 와 양념으로 제조한 김치의 경우 신냄새, 신맛 등의 지표에 서 김치형태로 저장된 것보다 유의적으로 낮은 점수를 받았 다. 전반적인 기호도에서도 분리 저장 후 제조한 김치에서 높은 점수를 받았으나 유의적인 차이는 확인되지 않았다. 이상의 결과, 절임배추와 양념으로 제품화할 경우 절임배 추는 품질유지를 위해 염수에 침지하여 포장하는 방법이 효과적이며, 분리 저장된 절임배추와 김치 양념을 혼합하 여 김치로 제조하여도 처음부터 김치 형태로 제조하여 저장 한 것과 비교하여 발효가 지연되면서 관능적으로도 문제가 없어 김치의 가식기간을 연장할 수 있는 방법이 될 것으로 생각된다.

\section{감사의 글}

본 연구는 세계김치연구소 기관고유사업(KE1503-3)의 연구비 지원을 받아 수행되었으며, 이에 감사드립니다.

\section{References}

1. Chambers IV E, Lee JH, Chun SS, E. Milleri AE (2012) Development of a lexicon for commercially available cabbage (Baechu) kimchi. J Sens Stud, 27, 511 - 518

2. Kim JM, Kim IS, Yang HC (1987) Storage of salted Chinese cabbages for kimchi. J Korean Soc Food Nutr, $16,75-82$
3. Ku KH, Jeong MC, Chung SK (2013) Industrialization of salted Chinese cabbages and fresh-cut Chinese cabbage. Food Science and Industry, 46, 2-11

4. Park YH, Kim YS, Kim SB (2009) Consumer preference for salted cabbage in Gyeonggi province. Food Science and Industry, 4, 28-34

5. Kim YW, Jeong JK, Lee SM, Kang SA, Lee DS, Kim SH, Park KY (2009) Effect of permeability-controlled polyethylene film on extension of shelf-life of brined Baechu cabbage. J Korean Soc Food Sci Nutr, 38, 1767-1772

6. Kim YW, Jung JK, Cho YJ, Lee SJ, Kim SH, Park KY, Kang SA (2009) Quality changes in brined Baechu cabbage using different types of polyethylene film, and salt content during storage. Korean J Food Preserv, 16, 605-611

7. Han ES, Seok MS, Park JH (1998) Quality changes of salted Baechu with packaging methods during long term storage. Korean J Food Sci Technol, 30, 1307-1311

8. Park SS, Sung JM, Jeong JW, Park KJ, Lim JH (2013) Quality changes of salted chinese cabbages with electrolyzed water washing and a low storage temperature. J Korean Soc Food Sci Nutr, 42, 615-620

9. Koh HY, Lee H, Yang HC (1993) Quality changes of salted Chinese cabbage and kimchi during freezing storage. J Korean Soc Food Nutr, 22, 62-67

10. Ku KH (2015) Development of storage and on-site salted cabbage production technology for stabilization of supply chain of Kimchi cabbage. Final Report of MAFRA, MAFRA 11-15430000-001177-01

11. Park SH, Lee JH (2006) Consumer acceptance and sensory characteristics of kimchi prepared with different kinds of subsidiary ingredients. Korean J Food Cook Sci, 22, 370-378

12. Park WS, Lee IS, Han YS, Koo YJ (1994) Kimchi preparation with brined Chinese cabbage and seasoning mixture stored separately. Korean J Food Sci Technol, 26, 231-238

13. Lee IS, Kim HY, Kim EJ (2004) A survey on the commercial poggi kimchi and consumer acceptance test prepared in the various region. J Korean Soc Food Cult, 19, 460-467

14. No HK, Lee SH, Kim SD (1995) Effects of ingredients on fermentation of Chinese cabbage kimchi. J Korean Soc Food Sci Nutr, 24, 642-650

15. Ku KH, Sunwoo JY, Park WS (2005) Effects of ingredients on the its quality characteristics during kimchi 
fermentation. J Korean Soc Food Sci Nutr, 34, 267-276

16. Nha YA, Park JN (2003) Effect of dried powders of pine needle, pine pollen, green tea and horseradish on preservation of kimchi-yangnyum. Culinary Science \& Hospitality Research, 9, 179-190

17. Choi TK, Park SH, Yoo JH, Lim HS, Jo JS, Hwang SY (2003) Effect of starter and salt-fermented anchovy extracts on the quality of kimchi sauce and Geotjeori kimchi. J Korean Soc Food Cult, 18, 96-104

18. Kim SD (1997) Preparation of kimchi and salting. Korean J Food Preserv, 4, 215-225

19. Choi EJ, Jeong MC, Ku KH (2015) Effect of seasonal cabbage cultivar (Brassica rapa L. ssp. Pekinesis) on the quality characteristics of salted-Kimchi cabbages during storage period. Korean J Food Preserv, 22, 303-313

20. Han ES (1994) Quality changes of salted Chinese cabbage by packaging methods during storage. Korean J Food Sci Technol, 26, 283-287

21. Park WP (2004) Quality characteristics of salted Chinese cabbage treated with electrolyzed-acid water during storage. Korean J Food Sci Technol, 36, 365-367

22. Hwang ES (2010) Changes in myrosinase activity and total glucosinolate levels in Korean Chinese cabbages by salting conditions. Korean J Food Cook Sci, 26, 104-109

23. Lee MK, Yang HJ, Woo HN, Rhee YK, Moon SW (2011) Changes in the texture and salt content of Chinese cabbage using different salting methods. J Korean Soc Food Sci Nutr, 40, 1184-1188

24. Kim SD, Park HD, Kim MK (1997) Morphological characteristics and composition of cell wall polysaccharides of Brassica campestris var. pekinensis (Baechu). Korean J Food Preserv, 4, 301-309

25. Lee CH, Hwang IJ, Kim JK (1988) Macro-and microstructure of Chinese cabbage leaves and their texture measurements. Korean J Food Sci Technol, 20, 742-748

26. Yun JY, Jeong JK, Moon SH, Park KY (2014) Effects of brined Baechu cabbage and seasoning on fermentation of kimchi. J Korean Soc Food Sci Nutr, 43, 1081-1087

27. Jeong JK, Park SE, Lee SM, Choi HS, Kim SH, Park KY (2011) Quality changes of brined Baechu cabbage prepared with low temperature stored Baechu cabbages. J Korean Soc Food Sci Nutr, 40, 475-479

28. Kim JH, Park JG, Lee JW, Kim WG, Chung YJ, Byun MW (2008) The combined effects of $\mathrm{N}_{2}$-packaging, heating and gamma irradiation on the shelf-stability of kimchi, Korean fermented vegetable. Food Control, 19, 56-61

29. Park JG, Kim JH, Park JN, Kim YD, Kim WG, Lee JW, Hwang HJ, Byun MW (2008) The effect of irradiation temperature on the quality improvement of kimchi, Korean fermented vegetables, for its shelf stability. Radiat Phys Chem, 77, 497-502

30. Lee JW, Cha DS, Hwang KT, Park HJ (2003) Effects of $\mathrm{CO} 2$ absorbent and high-pressure treatment on the shelf-life of packaged kimchi products. Int J Food Sci Tech, 38, 519-524

31. Choi YM, Whang JH, Kim JM, Suh HJ (2006) The effect of oyster shell powder on the extension of the shelf-life of kimchi. Food Control, 17, 695-699 